Review

\title{
State of the Art in Tumor Antigen and Biomarker Discovery
}

\author{
Klervi Even-Desrumeaux, Daniel Baty and Patrick Chames *
}

INSERM U624, 163 avenue de Luminy, 13288 Marseille Cedex 09, France;

E-Mails: klervi.even@inserm.fr (K.E.-D.); daniel.baty@inserm.fr (D.B.)

* Author to whom correspondence should be addressed; E-Mail: patrick.chames@ inserm.fr; Tel.: +33-4-91828833; Fax: +33-4-91826083.

Received: 6 April 2011; in revised form: 24 May 2011 / Accepted: 27 May 2011 /

Published: 9 June 2011

\begin{abstract}
Our knowledge of tumor immunology has resulted in multiple approaches for the treatment of cancer. However, a gap between research of new tumors markers and development of immunotherapy has been established and very few markers exist that can be used for treatment. The challenge is now to discover new targets for active and passive immunotherapy. This review aims at describing recent advances in biomarkers and tumor antigen discovery in terms of antigen nature and localization, and is highlighting the most recent approaches used for their discovery including "omics" technology.
\end{abstract}

Keywords: tumor antigen; biomarkers; immunotherapy; cancer; proteomics

\section{Introduction}

Cancer remains the major devastating disease throughout the world. Cancers are responsible for over 6 million deaths per year worldwide with at least 10 million new cases annually. In developing countries, cancer is the second most common cause of death, comprising 23\%-25\% of total mortality. Current treatments include chemotherapy and radiotherapy but these are often characterized by a low efficiency and a high level of toxicity.

More targeted therapies are eagerly awaited. Among them, immunotherapies, including any approach aiming at triggering an immune response toward tumor cells, are being actively pursued. The immune system is trained at recognizing and destroying non-self, such as pathogens and transformed cells. However, the immune system is much more efficient at recognizing and attacking germs than cancer cells. In many cases, differences between normal and cancer cells remain subtle and the 
immune system may not always recognize cancer cells as foreign. Moreover, cancer cells have evolved several strategies to dampen or evade immune responses, leading to cancer spread in the presence of a healthy, working immune system. To overcome this issue, researchers are studying several ways to help the immune system to recognize and destroy cancer cells. Two main types of immunotherapy can be distinguished [1]. Active immunotherapies aim at stimulating the patient's immune system to fight the disease. Passive immunotherapies do not rely on patient's bodies to initiate the immune response but rely on the use of man-made immune components, such as antibodies.

Monoclonal antibodies (mAbs) are the most common form of passive cancer immunotherapy [2]. Once antibodies are injected, they are retained at the tumor site because of their affinity for a tumor antigen. Their mode of action can be direct (for example via induction of apoptosis) or indirect, via the recruitment of effector cells or through the activation of the complement cascade leading to tumor cell lysis. These latter two modes of action are referred to as antibody-dependent cell-mediated cytotoxicity (ADCC) and complement dependent cytotoxicity (CDC) and are mediated through the Fc portion of mAbs. In the case of soluble antigens, mAbs can sequester the target and avoid their interaction with their receptor. From 1980 to 2010, several hundreds of therapeutic mAb have been studied in clinical trials by commercial companies worldwide for a variety of cancer indications. To date, 11 anticancer $\mathrm{mAb}$ have been approved by the US FDA for marketing.

Active immunotherapies are mainly developed as cancer vaccines [3]. Unlike regular vaccines, most cancer vaccines are not designed to prevent diseases but rather aim at raising a specific immune response against existing tumor cells. Cancer vaccines may contain cancer cells, parts of cells, or pure antigens. Interestingly, because a successful immune response is generating memory cells capable of being rapidly activated to destroy the same kind of cells, cancer vaccines have the potential to prevent relapses. Cancer vaccines have been studied for several decades, but advances in this field have been slower than for other forms of immunotherapy. However, several experimental treatments are currently leading to encouraging results. And recently, a prostate cancer vaccine has been approved by the FDA to treat advanced prostate cancer [4,5].

The treatment of cancer remains a formidable challenge owing to factors such as difficulties in differentiating tumor cells from healthy cells to fight the disease without causing intolerable toxicity. Much has changed in the last years due to the significant progress in immunology, molecular biology and completion of human genome sequence. Substantial antigenic differences have been found between tumors and normal tissues. A milestone in tumor immunology was the cloning of tumor antigen MAGE-1 by Boon's team in 1991 [6], and subsequent characterization of the first HLA-restricted T cell defined antigenic epitope a year later [7]. Because tumor-specific antigens are exclusively expressed by cancer cells and are often critical for tumorigenicity, they are ideal targets for anti-cancer therapy. However, targeting tumor-specific antigens would require therapeutic strategies to be made to individual patients or small subgroups of patients. Thus, until now mainly tumor-associated shared antigens have been targeted by active and passive cancer immunotherapy. Identification of new tumor antigens may lead to the development of future antigen-specific immunotherapy to tumors. Interestingly, such tumor antigens are often released in the circulation and can be used as biomarkers. More generally, cancer biomarkers can be defined as markers produced either by the tumor itself or by other tissues, in response to the presence of cancer or other associated conditions, such as inflammation. Biomarkers might be DNA, mRNA, proteins, metabolites, or processes such as apoptosis, angiogenesis or proliferation. 
Such biomarkers can be found in a variety of fluids, tissues and cell lines. They are commonly employed in clinical diagnosis. For example, they can be used to diagnose cancer in an early phase, to subtype within a disease category and to monitor patients for response to therapy. Over the past several decades, enormous efforts have been made to screen and characterize useful cancer biomarkers. Some important molecules including carcinoembryonic antigen (CEA), human epidermal growth factor receptor-2 (HER2/neu), prostate specific antigen (PSA), alpha-fetoprotein (AFP), cancer antigen or carbohydrate antigen (CA 125, CA 15-3 and CA 19-9), have been identified. Interestingly, several biomarkers including HER2, CEA, PSA, mucin-1 (MUC-1) are also used in immunotherapy as tumor antigens.

Immunotherapy has been studied for several decades and has led to several encouraging result. The discovery of new tumor antigens could help to expand these approaches to a wider variety of cancers. Moreover, it is also important to discover new markers for other clinical applications such as diagnosis and prognosis. This review aims at describing the state of the art on current tumor antigens used in immunotherapy, and highlights the recent advances in biomarker and tumor antigen discovery approaches.

\section{Antigens Used in Immunotherapy}

\subsection{Tumor Antigens: Definition}

Based on qualitative differences, tumor antigens are divided into two classes: Tumor-specific antigens (TSAs) that are caused by mutations and tumor-associated antigens (TAAs) that result from over- or aberrant expression of non-mutated proteins.

TAAs represent a group of normal non-mutant molecules that can be subdivided into four major categories according to expression pattern [8]: (1) Cancer-testis like antigens (CT antigens): CT antigens include MAGE-1 [6,9], MAGE-2, MAGE-3, MAGE-12, BAGE, GAGE, NY-ESO-1, and CML66, and CML28 [10]. Cancer-testis antigen are expressed in a wide range of different cancers, but are generally not expressed in most other normal somatic tissues, except testis [11]. Since testis is an immune privileged site that does not express MHC class I or II molecules [12], these antigens can practically be regarded as tumor-specific and are highly desirable as targets for antigen-specific immunotherapy; (2) Differentiation antigens: Differentiation antigens are tyrosinase, TRP-1, TRP-2, gp100, MART-1, CD20, epithelial cell adhesion molecule (EpCAM) and MC1R [13,14]. Since these differentiation antigens are expressed in differentiation stage-dependent and tissue-specific manners, immunotherapy based on these antigens may not cause any side-effects on the other tissues; (3) Oncofoetal antigens: These antigens are found on embryonic and fetal tissues as well as certain cancers. This category includes CEA, $\alpha$-fetoprotein, 5T4, onco-trophoblast, and solid tumor associated glycoprotein $[8,15]$; (4) Overexpressed antigens: These antigens are normal proteins whose expression is up-regulated in cancer cells. Examples include PSA, prostatic acid phosphatase (PAP), proteinase 3 (myeloblastin), WT-1, MUC-1, wild-type p53, Her2/Neu, G250, prostate specific membrane antigen (PSMA) and epidermal growth factor receptor (EGFR) [16-19]. Because of their expression in normal tissue, TAAs are more likely to have induced immunologic tolerance [20]. Self-reactive T cells are deleted or inactivated, and when not deleted, have a reduced capacity to recognize target antigens [21]. If a cancer vaccine does break tolerance to TAAs, destruction of normal tissues or even fatal autoimmune damage might result from the generation of self-reactive T cells [22,23]. 
The second group of antigens is TSAs. Cancer results from the accumulation of somatic mutations, and cancer cells contain a large number of mutant proteins [24] than can be recognized as TSAs in an individual patient. With the large number of mutations found in common human cancers [25,26], every human cancer cell should harbor at least few mutations that can be therapeutically exploited, if the corresponding peptide can be efficiently presented by HLA molecules. TSAs are ideal targets for cancer immunotherapy because they are exclusively expressed by cancer cells and not on non-malignant tissues, minimizing the risk of autoimmune destruction. During tumor development, the immune system can recognize these determinants as non-self and generate specific high-affinity antibodies and T cells against them. Advantages of tumor-specific antigens include immunogenicity, decreased risk of inducing autoimmunity, decreased risk of immune escape and immunodominance, which make tumor-specific antigens attractive targets for immunotherapy. However, unlike TAAs, TSAs are expressed only on individual patient's cancer cells or small subsets of tumors and thus require the development of personalized therapy. Examples of TSA include three Ki-RAS point mutations (single amino acid substitutions) that are found in about $95 \%$ of all patients with pancreatic cancer. Another example can be given with mutated p53. The pivotal role of p53 as a tumor suppressor is illustrated by the fact that this protein is found mutated in $~ 50 \%$ of human cancers. In most cases, mutations in p53 greatly increase the otherwise short half life of this protein and cause it to accumulate in tumor cells. The aberrant p53 expression in many malignancies offers an attractive opportunity for antigen-specific immunotherapy of cancer [27]. This is because the mutated p53 that is present in tumor cells may be considered "nonself" or tumor specific [28]. The tumor specific mutations present in the p53 protein may alter its antigenicity, if the mutations occur in a region of the protein that can be presented as an epitope to the T cell.

Over the last 10 years, the genetic origins of several TSAs have been identified but in each case the mutations identified were only found in one individual tumor but not in cancer cells from other patients [29,30]. However, once more cancers are analyzed, prominent target genes and mutation patterns will likely emerge. Improvements in "omics" technology and database information should soon make such individually tailored therapies a reality.

\subsection{Passive Immunotherapy}

Passive immunotherapies use immune system components such as mAbs to attack the disease [31]. Naked mAbs are currently the most commonly used mAbs. Although they all work by binding to specific antigens, they use various mode of action. Some naked mAbs bind cancer cells to act as a marker for the body's immune system to destroy them. Such approved antibodies include: Rituximab, Ofatumumab and Alemtuzumab (Table 1). The effects of other naked antibodies come from their ability to bind to some receptors or ligands, thereby blocking their interactions with their cognate ligand or receptor, and avoiding some signaling necessary to the proliferation of cancer cells. Examples of FDA-approved mAbs of this type include: Trastuzumab, Cetuximab, Panitumumab and Bevacizumab (Table 1). By contrast, conjugated mAbs are monoclonal antibodies that are linked to drugs, toxins, or radioactive substances. The mAbs are used as transporters to deliver these substances directly to cancer cells. Conjugated mAbs can be divided into groups depending on what they are linked to. MAbs linked to radioactive particles are referred to as radiolabeled, and therapy with this 
type of antibody is known as radioimmunotherapy (RIT). Two radiolabeled antibodies have been approved to treat cancer: Ibritumomab tiuxetan and Tositumomab (Table 1). MAbs linked to chemotherapy drugs attached are often referred to as chemolabeled and mAbs linked to toxins are called immunotoxins. There are no chemolabeled or immunotoxins approved for cancer therapy so far.

Table 1. Monoclonal antibodies approved by Food and Drug Administration (US) or European Medical Agency (EU).

\begin{tabular}{|c|c|c|c|c|}
\hline Product & Type & Target & Indications & $\begin{array}{l}\text { Date of } \\
\text { approved }\end{array}$ \\
\hline $\begin{array}{l}\text { Rituximab } \\
\text { (Rituxan) }\end{array}$ & Chimeric & CD20 & Non-Hodgkin's lymphoma & $\begin{array}{l}1997 \text { (US) } \\
1998(\mathrm{EU})\end{array}$ \\
\hline $\begin{array}{l}\text { Trastuzumab } \\
\text { (Herceptin) }\end{array}$ & Humanized & HER2 & Metastatic breast cancer & $\begin{array}{l}1998(\mathrm{US}) \\
2000(\mathrm{EU})\end{array}$ \\
\hline $\begin{array}{l}\text { Gentuzumab } \\
\text { (Mylotarg) }\end{array}$ & $\begin{array}{l}\text { Humanized, } \\
\text { (coupled to } \\
\text { calicheamicin) }\end{array}$ & CD33 & Acute myeloid leukemia & 2000 (US) \\
\hline $\begin{array}{l}\text { Alemtuzumab } \\
\text { (Campath) }\end{array}$ & Humanized & CD52 & Chronic lymphocytic leukemia & $\begin{array}{l}2001 \text { (US) } \\
2001(\mathrm{EU})\end{array}$ \\
\hline $\begin{array}{l}\text { Ibritumomab } \\
\text { tiuxetan } \\
\text { (Zevalin) }\end{array}$ & $\begin{array}{l}\text { Chimeric } \\
\left({ }^{90} \mathrm{Y} \text { radiolabelled }\right)\end{array}$ & $\mathrm{CD} 20$ & Non-Hodgkin's lymphoma & $\begin{array}{l}2002 \text { (US) } \\
2004(\mathrm{EU})\end{array}$ \\
\hline $\begin{array}{l}\text { Tositumomab } \\
\text { (Bexxar) }\end{array}$ & $\begin{array}{l}\text { Murine } \\
\left({ }^{131} \text { I radiolabelled }\right)\end{array}$ & $\mathrm{CD} 20$ & Non-Hodgkin's lymphoma & 2003 (US) \\
\hline $\begin{array}{l}\text { Cetuximab } \\
\text { (Erbitux) }\end{array}$ & Chimeric & EGFR & Metastatic colorectal cancer & $2004(\mathrm{EU})$ \\
\hline $\begin{array}{l}\text { Bevacizumab } \\
\text { (Avastin) }\end{array}$ & Humanized & VEGF-A & Metastatic colorectal cancer & $\begin{array}{l}2004 \text { (US) } \\
2005 \text { (EU) }\end{array}$ \\
\hline $\begin{array}{l}\text { Panitumumab } \\
\text { (Vectibix) }\end{array}$ & Human & EGFR & Metastatic colorectal cancer & $\begin{array}{l}2006 \text { (US) } \\
2007 \text { (EU) }\end{array}$ \\
\hline $\begin{array}{l}\text { Catumaxomab } \\
\text { (Removab) }\end{array}$ & $\begin{array}{l}\text { Hybrid rat and mouse } \\
\text { (trifunctional } \\
\text { bispecific) }\end{array}$ & EpCam & Malignant ascites & $2009(\mathrm{EU})$ \\
\hline $\begin{array}{l}\text { Ofatumumab } \\
\text { (Arzerra) }\end{array}$ & Human & $\mathrm{CD} 20$ & Chronic lymphocytic leukemia & 2009 (US) \\
\hline
\end{tabular}

The efficacy of anti-cancer mAbs is critically dependent on the nature of the target. An ideal tumor cell surface target should be accessible, abundant, homogeneous and consistently present on the surface of cancer cells within a tumor [32]. Importantly, targets should not be expressed on normal cells, especially those that constitute vital organs, so that anti-cancer mAbs can discriminate between healthy and malignant cells. Ideally, targets should not be secreted in any form by the tumor cells into the circulation because anti-cancer mAbs might bind to the soluble circulating antigen rather than the antigen presented by tumor cells. If ADCC or CDC modes of action are desired, the antigen-mAb complex should not be rapidly internalized by the cell because the Fc portion cannot activate the immune system. By contrast, internalization is necessary for cytotoxic activity in the case of some immunotoxins. These targets must be capable of antibody mediated internalization, or have an 
intrinsically high turnover rate. Candidate therapeutic mAbs currently investigated in clinical studies are targeting approximately 80 different antigens (Table 2) [33]. However, only 10 different antigens are currently being targeted by mAbs developed for cancer therapies: EpCAM, MUC1, EGFR, CD20, CEA, HER2, CD22, CD33, Lewis Y and PSMA. The small size of this set clearly highlights the necessity to discover new tumor targets.

Table 2. Main tumor antigens used in clinical studies using mAb therapy.

\begin{tabular}{|c|c|c|}
\hline Target & Antigen class/description & $\begin{array}{l}\text { Number of } \\
\text { mAbs* }\end{array}$ \\
\hline EpCam (Epithelial cell adhesion molecule) & Cellular adhesion & 17 \\
\hline EGFR (Epidermal growth factor receptor) & Growth factor receptor & 12 \\
\hline $\mathrm{CD} 20$ & $\mathrm{CA} 2+$ channel & 10 \\
\hline MUC1 (Mucin 1) & Mucin & 10 \\
\hline $\begin{array}{l}\text { HER2 (Human epidermal growth factor } \\
\text { receptor 2) }\end{array}$ & Growth factor co-receptor & 9 \\
\hline CEA (Carcinoembryonic antigen) & Oncofetal glycoprotein, cellular adhesion & 9 \\
\hline CD22 (Siglec-2) & $\begin{array}{l}\text { Sialoadhesin, sialic acid-binding } \\
\text { immunoglobulin-like lectine }\end{array}$ & 6 \\
\hline CD33 (Siglec-3) & $\begin{array}{l}\text { Sialoadhesin, sialic acid-binding } \\
\text { immunoglobulin-like lectine }\end{array}$ & 6 \\
\hline LEWIS Y & Carbohydrate & 6 \\
\hline $\begin{array}{l}\text { PSMA (Prostate-specific membrane } \\
\text { antigen) }\end{array}$ & $\begin{array}{l}\text { Glycoprotein with folate hydrolase and } \\
\text { NAALADase activities }\end{array}$ & 6 \\
\hline $\begin{array}{l}\text { TAG-72 (Tumor-associated glycoprotein } \\
\text { 72) }\end{array}$ & Mucin like glycoprotein & 5 \\
\hline CD30 (TNFRSF1) & TNF receptor super family & 4 \\
\hline CD19 & B-lymphocyte antigen & 3 \\
\hline CD44V6 & Adhesion molecule & 3 \\
\hline CD56 (NCAM) & Cellular adhesion & 3 \\
\hline GD2 ganglisoside & Glycosphingolipid & 3 \\
\hline GD3 ganglisoside & Glycosphingolipid & 3 \\
\hline $\begin{array}{l}\text { HLA-DR10 (Human leukocyte antigen- } \\
\text { DR) }\end{array}$ & MHC class II receptor & 3 \\
\hline $\begin{array}{l}\text { IGF1R (Insulin-like growth factor } 1 \\
\text { receptor) }\end{array}$ & Tyrosine kinase receptor & 3 \\
\hline TAL6 (Tumor-associated antigen L6) & Members of the transmembrane- 4 superfamily & 3 \\
\hline $\begin{array}{l}\text { TRAILR2 (Tumor-necrosis factor-related } \\
\text { apoptosis-inducing ligand receptor) }\end{array}$ & Member of the tumor necrosis factor family & 3 \\
\hline $\begin{array}{l}\text { VEGFR2 (Vascular endothelial growth } \\
\text { factor receptor 2) }\end{array}$ & Angiogenic growth factor receptor & 3 \\
\hline CD152 (CTLA4) & Negative regulator of $\mathrm{T}$ cell activation & 2 \\
\hline Unknown & & 11 \\
\hline
\end{tabular}

\footnotetext{
* mAbs in clinical studies between 1980 and 2005 [28].
} 


\subsection{Active Immunotherapy}

During the last decades, various strategies have been proposed to overcome the poor immune response against TAAs, including cell-based vaccines, DNA- or RNA-based vaccines, protein or peptides based vaccines, and vector based vaccines [34]. The common rational for all these modalities is the activation of antigen presenting cells (APCs) and the stimulation of an antigen-specific cytotoxic T lymphocyte (CTL) mediated immune response (Table 3).

Table 3. Overview of different vaccination strategies.

\begin{tabular}{|c|c|c|c|c|c|}
\hline $\begin{array}{l}\text { Vaccine } \\
\text { Type Name }\end{array}$ & & Phase & Tumor & Antigen & References \\
\hline \multirow{3}{*}{$\begin{array}{l}\text { Viral } \\
\text { vectors }\end{array}$} & $\begin{array}{l}\text { PSA- } \\
\text { TRICOM }\end{array}$ & II & Prostate & PSA & [31-34] \\
\hline & PANVAC-VF & III & Pancreatic & CEA, MUC1 & [35-37] \\
\hline & TG4010 & II & $\begin{array}{l}\text { Breast, } \\
\text { prostate, } \\
\text { lung }\end{array}$ & MUC1, IL2 & [38-40] \\
\hline \multirow{3}{*}{ Peptides } & Provenge & III & Prostate & PAP & {$[1,2]$} \\
\hline & Oncophage & III & $\begin{array}{l}\text { Melanoma, } \\
\text { Renal }\end{array}$ & HSPg96 & {$[42,43]$} \\
\hline & Stimuvax & II & Lung & $\begin{array}{l}\text { Extracellular core peptide of } \\
\text { MUC1 }\end{array}$ & [41] \\
\hline \multirow{3}{*}{$\begin{array}{l}\text { Tumor cells } \\
\text { or tumor- } \\
\text { cell lysates }\end{array}$} & OncoVAX & III & Colon & Irradiated tumor cells & [44] \\
\hline & Renial & III & Renal & $\begin{array}{l}\text { Lysate of autologous tumor } \\
\text { cells }\end{array}$ & {$[44,45]$} \\
\hline & GVAX & III & Prostate & $\begin{array}{l}\text { Irradiated humn prostate } \\
\text { cancer cell lines LNCaP and } \\
\text { PC-3 }\end{array}$ & {$[35]$} \\
\hline RNA & $\begin{array}{l}\text { mRNA from } \\
\text { Pca cell lines }\end{array}$ & II & Prostate & PSA & {$[57]$} \\
\hline
\end{tabular}

A first vaccination strategy relies on the use of vectors. Several vectors can be used to deliver recombinant genes (including genes expressing TAAs, costimulatory molecules, or cytokines) into APCs. Recombinant vector-based vaccines may induce the immune system to generate a response against the genes of interest that have been inserted into the vector. One advantage of using vectors as vehicles for TAAs is that this type of delivery of a recombinant protein is much more immunogenic than the administration of the protein with adjuvants [35]. Vectors used in cancer immunotherapy include viral, bacterial, and yeast vectors. Poxviral vectors are among the most heavily exploited in vaccine development. The large genome of poxviruses (approximately $130 \mathrm{~kb}$ for mammalian poxviruses and $300 \mathrm{~kb}$ for avian poxviruses) allows for insertion of more than $10 \mathrm{~kb}$ of foreign DNA. Moreover, gene products are usually expressed at high levels, resulting in a potent cellular immune response. Two vector vaccines are actually in clinical trials: PSA-TRICOM vaccine (prostate-specific antigen plus a TRIad of Costimulatory Molecules; PROSTVAC) [36-39] and PANVAC-VF, another poxviral-based vaccine that consists of a priming vaccination with recombinant vaccinia encoding CEA(6D), MUC1(L93), and TRICOM plus booster vaccinations with recombinant fowlpox expressing 
the identical transgenes [40-42]. TG4010 is another vaccine. It incorporates the MUC1 antigen, which is overexpressed in the majority of cancers, into a non-propagative pox viral vector, MVA. A second gene, interleukin-2 is also incorporated into TG4010 as an immune stimulus. The vaccine has been tested in breast, kidney, prostate and lung cancers with encouraging results [43-45] (Table 3).

The second method relies on the use of proteins or peptides to stimulate a specific immune response against cancer and employs single agents or combinations of proteins, heat-shock proteins (HSPs), peptides and agonist peptides, antiidiotype antibodies, and fusion proteins. These protein- or epitopebased vaccines have two main advantages over the use of tumor cells or lysates: Production, storage, and distribution are faster and more cost-effective, and the identification and administration of TSAs is preferable since tumor-cell preparations mostly contain self-proteins with no therapeutic benefit and are potentially capable of generating an autoimmune response. On the other hand, this approach has certain drawbacks: Single protein or, especially, a single epitope are sometimes weakly immunogenic. Tumors can easily escape immune recognition through antigen mutation. Their use is HLA restricted (mainly for epitope-based vaccines) and limited to a subset of patients (usually HLA-A2+). They have a poor ability to induce balanced activation of CD4 and CD8 subsets, which is thought to be essential for effective antitumor immunity. The use of specific proteins or peptides as targets for immunotherapy clearly requires a careful choice of the targeted TSAs or TAAs and their epitopes, involving knowledge of their structural and functional characteristics. Single-peptide epitope composed of 8 to 10 amino acids are able to induce a CTL response by binding to MHC class I molecules expressed on APCs. Several antigen vaccines are actually in clinical trials (Table 3) [4,5,46-48]. Provenge (sipuleucel$\mathrm{T}$, Dendreon Corporation), recently approved by FDA, is an autologous cellular immunotherapy from T cells designed to stimulate T-cell immunity against prostatic acid phosphatase (PAP) [4,5] (Table 3). Stimuvax (BLP25 liposome vaccine, L-BLP25, Oncothyreon partnered with Merck KGaA) is a cancer vaccine designed to induce an immune response against the extracellular core peptide of MUC1, a type I membrane glycoprotein widely expressed on many tumors (i.e., lung cancer, breast cancer, prostate cancer, and colorectal cancer) [46] (Table 3). To avoid the disadvantages of using short peptides, the concept of synthetic long peptides (SLP) has been developed as vaccines [49]. When injected, these SLPs are predominantly taken up by dendritic cells resulting in the presentation of both helper T-cell epitopes and CTL epitopes that are present in the SLP [50]. In a recent study, a p53-SLP vaccine was found capable of inducing p53-specific T-cell responses in patients treated for colorectal cancer [27].

The third strategy of vaccine is the use of tumor-cells or lysates [40,51,52]. Tumor-cell vaccines have at least three advantages over the single-target approaches in terms of eliciting an immune response: Different and unknown antigens can be targeted at the same time, the immune response is not HLA-restricted, the variety of both MHC class I and class II epitopes processed is likely to be able to stimulate both an innate (natural killer cells, macrophages, and eosinophils) and adaptive (CD8+ and $\mathrm{CD} 4+\mathrm{T}$ cells) response. The first important distinction is between vaccines using autologous (patient-specific) or allogeneic (non patient-specific) tumor cells. Second, these cells may be unmodified, modified for expression of $\mathrm{MHC}$, costimulatory molecules, or cytokines, or used in combination with adjuvants such as GM-CSF and Bacille Calmette-Guerin (BCG). Third, these cells can be used in the form of tumor-cell lysates [52]. In the past 20 years, several different vaccines derived from whole tumor cells or tumor-cell lysates have been evaluated in preclinical models and clinical trials. OncoVAX (Vaccinogen) is composed of autologous irradiated tumor cells, with or 
without BCG as an adjuvant [52]. Reniale (LipoNova) is a vaccine based on a lysate of autologous tumor cells, preincubated with IFN- $\gamma$ to increase the antigenicity of these cells, and tocopherol acetate to protect cell membranes during the incubation process [51,52] (Table 3).

The last strategy is DNA- or RNA-vaccines. In this case, cells are injected with DNA encoding protein antigens. DNA-based vaccines are a recently developed strategy that has proven capable of activating strong immunity against weak TAAs. Recently, several phase I/II clinical trials employing DNA-based vaccines targeting different TAAs (i.e., PSA, PAP, gp100, CEA, hsp65) have been conducted in patients with prostate cancer, melanoma, colorectal cancer, and head and neck carcinomas [53-57]. The mRNA-based vaccine containing the mRNA-coding TAA is transfected into DCs and translated into proteins. After protein processing, the antigen can be loaded on MHC molecules for antigen presentation, thus activating an antigen-specific CTL response. Clinical trials have been performed employing mRNA transfected DCs or injecting mRNA directly into patients with prostate cancer, renal cancer, ovarian cancer, lung cancer, breast cancer, pediatric brain cancer, neuroblastome, and melanoma [58-63]. A phase I clinical trial was performed using PSA-mRNA transfected DCs in patients with metastatic prostate cancer [64] (Table 3).

\subsection{Glycoproteins: A New Avenue}

Until recently, tumor-specific tumor antigens that have been identified in mouse and human are mutant peptide epitopes. In eukaryotic cells, $95 \%$ of all proteins are post-translationally modified and glycosylation is the most frequent post-translational modification found. It is estimated that $50 \%-80 \%$ of cellular proteins-Membrane, cytosolic and nuclear-are glycosylated [65]. Although the amino acid sequence of proteins predominantly determines their three-dimensional structure, the post-translational modifications of the proteins modulate their physical and chemical properties and thus their stability and molecular function. Since glycoproteins, carbohydrates and glycolipids are the most abundant structures present on the surface of eukaryotic and prokaryotic cells, they are the first structures encountered by the immune system. Initially, it was thought that only pure protein epitopes could be presented on MHC and induces T cell responses. This was due in part to the observation that immunization with carbohydrate antigens usually resulted in low-affinity IgM responses without memory. To obtain a strong immune response, as reflected by IgG production, both $\mathrm{T}$ and $\mathrm{B}$ cells are required. However, recent publications have demonstrated that non-peptide molecules such as pure carbohydrates, glycopeptides and glycolipids can be presented on MHC molecules and recognized by $\mathrm{T}$ cells [66-73]. Although pure peptide epitopes are still considered as the primary targets for $\mathrm{T}$ cell responses, there is agreement that glycopeptides also induce $\mathrm{T}$ cell responses $[68,70,72,73]$. Therefore, the peptide epitopes that have been identified thus far as tumor epitopes might represent only a small fraction of potential targets. There are two types of glycosylation, $N$ - and $O$-glycosylation [74,75]. $N$-Glycosylation occurs at the amino acid asparagine (Asn). The consensus sequence for $N$-glycosylation is the presence of the amino acid sequence Asn- $X$-serine/threonine ( $X$ may be any amino acid except proline). $O$-Glycosylation occurs at serine (Ser) or threonine (Thr) residues, but despite much effort, no consensus sequence for $O$-glycosylation has been identified. Aberrant glycosylation has been recognized for more than 30 years as a typical feature of cancer [74-80]. Changes in cell surface carbohydrate structures occur during tumor progression, invasion and 
metastasis [81]. Cancer cells frequently display glycoproteins with increased branching of the glycan structures and/or altered expression levels compared with normal cells [82]. Such aberrations occur in both $N$ - and $O$-linked glycosylation. Due to their wide expression profile in several malignancies, much effort has gone into targeting tumor-associated carbohydrate antigens (TACAs) with active and passive immunotherapy and trying to augment their antigenicity and immunogenicity [83-85]. In addition to TACAs, gangliosides (GD3, GD2 and GM2) have also emerged as promising mAb targets for various cancers such as melanoma and neuroblastoma [78,86]. Intriguingly, many of the oldest and most widely used clinical cancer biomarker tests detect glycoproteins. These include CEA, commonly used as a marker of colorectal cancer, CA 125, frequently used to diagnose ovarian cancer and PSA for prostate cancer [87-93].

\subsection{Intact Intracellular Proteins as Tumor Antigens: The Intrabody Concept}

An intrabody (for intracellular antibody) is an antibody that has been designed to be expressed intracellularly, opening the possibility to specifically block a precise interaction of a antigen into the intracellular compartments of living cells. Intrabodies can be directed to a specific target antigen present in various subcellular locations including the cytosol, nucleus, endoplasmic reticulum (ER), mitochondria and trans-Golgi network (TGN). Combining specificity and antigen-binding affinity, intrabodies have been used as a biotechnological tool to interrupt, modulate, or define the functions of a wide range of target antigens at the posttranslational level. These intracellular antibodies are being developed to bind to, neutralize, or modify the function or localization of cancer-related targets and thereby affect the malignant phenotype.

There are many ways in which intrabodies could be used inside the cell to affect protein function [94,95]. Apart from blocking protein-protein or protein-nucleic acid interactions [96], it is possible to design intrabodies that bind antigen and relocate it to an inappropriate subcellular location. Intrabodies can also be employed to inhibit directly the function of an enzyme [97-99], or even to promote the death of target cells (e.g., cancer cells) by inducing caspase-3-mediated apoptosis [100]. In the field of cancer, intrabodies have been used to modulate the expression of proteins upregulated in tumors, such as erbB-2, interleukin-2 receptor, cyclin E (cell cycle protein), and EGFR [100-109]. In all these cases, appropriate cellular localization signals were fused to the intrabodies to reduce the activity of tumor-related proteins by altering their location. Oncogenic proteins, such as tumor protein 53 (p53) and proto-oncogen (RAS) [110], which are mutated in a large number of tumors are good candidates for intrabody therapy because they are tumor-specific therapeutic targets. A major challenge for the successful application of intrabodies for therapy is achieving sufficient internalization or expression inside target cells. Introducing intrabodies in vitro into cell lines in tissue can be achieved via gene expression using standard methods or by use of protein transduction domains linked to intrabodies [111]. Intrabody delivery in vivo represents another level of difficulty. Virally mediated gene transfer is a good option or an alternative approach would be to use immunoliposomes [112-114].

\subsection{Biomarkers}

A biomarker, according to the US national Cancer Institute, is a biological molecule found in blood, another body fluid or in tissues that is a sign of a normal or abnormal process. Generally, biomarkers 
are produced by either the tumor itself or other tissues, in response to the presence of cancer or other associated conditions. Historically, cancer protein biomarkers have been discovered in body fluids and tumor tissues (or cell lines) using two dimensional polyacrylamide gel electrophoresis (2D-PAGE) separations or by identifying immunogenic antigens on cancer cells [115]. Conventional approaches have successfully produced FDA-approved blood-based cancer biomarkers and most of which are used to monitor treatment [116] (Table 4). Tumor markers can be used for screening of a general population, for differential diagnosis in symptomatic patients, and for clinical staging of cancer. A number of different types and forms of tumor markers exist. These markers include hormones, as well as different functional subgroups of proteins such as enzymes, glycoproteins, oncofetal antigens and receptors.

Importantly, a number of biomarkers used in diagnosis are also tumor antigens used in cancer therapies. Relevant examples include CEA, HER2 and MUC-1 [117-19] (Table 4). These molecules are membrane proteins targeted use in immunotherapy. However, the extracellular domain of these proteins is shed into the bloodstream and can be detected in serum. Consequently, the discovery of new biomarkers for diagnostic purposes might also in some case be of high interest for the discovery of new tumor target for therapeutic approaches.

Table 4. Main cancer biomarkers and their applications.

\begin{tabular}{|c|c|c|c|}
\hline Biomarker & Cancer type & Clinical use in diagnosis & Clinical use in therapy \\
\hline CEA & Colon & Monitoring & Passive and active therapy \\
\hline $\begin{array}{l}\text { Alpha- } \\
\text { fetoprotein }\end{array}$ & Germ-cell hepatoma & Staging & not used \\
\hline CA125 & Ovarian & Monitoring & Passive therapy \\
\hline EGFR & Colon & Prognosis & Passive therapy \\
\hline KIT & Gastrointestinal & Diagnosis & Molecular therapy (Imatinib) \\
\hline Thyroglobulin & Thyroid & Monitoring & not used \\
\hline PSA & Prostate & Screening and monitoring & Passive and active therapy \\
\hline CA15-3 & Breast & Monitoring & not used \\
\hline CA27-29 & Breast & Monitoring & not used \\
\hline Cytokeratins & Breast & Prognosis & not used \\
\hline $\begin{array}{l}\text { Oestrogen and } \\
\text { progesterone } \\
\text { receptor }\end{array}$ & Breast & Prognosis & Hormonotherapy \\
\hline HER2 & Breast & Monitoring & Passive and active therapy \\
\hline Fibrin/FDP & Bladder & Monitoring & not used \\
\hline Mucin 1 & $\begin{array}{l}\text { Glandular epithelial } \\
\text { origin }\end{array}$ & Diagnosis, monitoring & Passive and active therapy \\
\hline CA19-3 & Pancreatic & Monitoring & not used \\
\hline
\end{tabular}




\section{Strategies of Discovery of New T-cell Antigen and Biomarkers}

Cancer is a complex disease that reflects genetic, as well as protein changes within a cell. During the past two decades, there has been a growing interest in approaches for discovering new biomarkers that may allow identification of potential targets for drug therapy. New biomarkers are urgently needed to accelerate efforts in developing new drugs and treatments of diseases. The explosion of high-throughput technologies available for generating large-scale molecular-level measurements in human populations has led to an increased interest in the discovery and validation of molecular biomarkers in medical research. Most biomarkers and tumoral antigen are not satisfactory because of their limited specificity and/or sensitivity. So, there is an urgent need to discover better targets in clinical practice. Global gene expression analysis has been extensively utilized, and the cancer management results are currently being translated into clinical tests, such as MammaPrint [120] and Oncotype DX [121] used for breast cancer. But gene expression data gives limited information since proteins are the main functional units performing all biological process in the cell or organism and may have post-transcriptional event(s) and post-translational modification(s) that contribute to the biological activity of proteins. The direct analysis of protein, the functional unit of the cell, using proteomics analysis has several advantages despite requiring more tissue and being more time-consuming. Several proteomics technologies including 2D-PAGE [122-124], surface enhanced laser desorption/ionisation time of flight (SELDI-ToF) [125], protein arrays [126,127], isotope coded affinity tags (ICAT), iTRAQ and multidimensional protein identification technology (MudPIT) are the approaches being implemented in cancer research (Table 5). 2D-PAGE and SELDI-ToF are the main technologies used in serum cancer research. However other technologies such as protein arrays, ICAT, iTRAQ and MudPIT also offer great potential for future biomarker discovery in cancer.

\subsection{T-cell Antigens}

One of the major contributions that proteomics has made to the medical and pharmaceutical community is the identification of potential drug targets. The identification and molecular characterization of self antigens expressed by human malignancies that are capable of elicitation of anti-tumor immune responses in patients has been an active field in tumor immunology. Much has changed in the last twenty years due to the significant progress in immunology, molecular biology and completion of human genome sequencing [128-130]. Substantial antigenic differences have been found between tumors and normal tissues. A great deal of evidence in mice and men has demonstrated that the host generates antibodies and $\mathrm{T}$ cells against developing tumors. Strategies have been developed to use patient's $\mathrm{T}$ cells (CD4+ and CD8+) and IgGs for the identification and characterization of tumor antigens. 
Table 5. Methods for protein expression studies.

\begin{tabular}{|c|c|c|c|}
\hline Methods & $\begin{array}{l}\text { Number of } \\
\text { proteins }\end{array}$ & Advantages & Disadvantages \\
\hline ELISA & One & $\begin{array}{l}\text { Well established, sensitive, specific, } \\
\text { wide applicability }\end{array}$ & Separate assay for each protein \\
\hline Western blotting & One & Wide applicability & Poor reproducibility \\
\hline $\begin{array}{l}\text { 2D-Gel } \\
\text { electrophoresis }\end{array}$ & Few thousand & Small costs, possibility of screening & Time-consuming \\
\hline $\mathrm{IHC}$ & One & Determination of protein localization & Separate assay for each protein \\
\hline TMA & One & Analysis of multiple samples & Problem of small tissue spot \\
\hline Planar antibody array & Few hundred & $\begin{array}{l}\text { Small sample volume, multiplexing } \\
\text { capabilities, sensitive }\end{array}$ & $\begin{array}{l}\text { Poor reproducibility, cross } \\
\text { reactivity, labeling }\end{array}$ \\
\hline RPPA & Few thousand & $\begin{array}{l}\text { Small sample volume, multiplexing } \\
\text { capabilities }\end{array}$ & Cross reactivity \\
\hline Bead array & $10-20(\max 100)$ & $\begin{array}{l}\text { Multiplexing, small sample volume, } \\
\text { wide applicability }\end{array}$ & Cross reactivity \\
\hline MALDI-SM & Few thousand & $\begin{array}{l}\text { Small sample volume, wide } \\
\text { applicability, screening }\end{array}$ & $\begin{array}{l}\text { Poor reproducibility, time- } \\
\text { consuming }\end{array}$ \\
\hline SELDI-SM & Few thousand & Small sample volume, screening & $\begin{array}{l}\text { Low sensitivity, time- } \\
\text { consuming }\end{array}$ \\
\hline SPR & One & $\begin{array}{l}\text { High sensitivity, small sample } \\
\text { volume, no labeling }\end{array}$ & No screening, time-consuming \\
\hline ICAT & Few thousand & $\begin{array}{l}\text { Protein quantification of low abundant } \\
\text { proteins }\end{array}$ & $\begin{array}{l}\text { tOnly cysteine containing } \\
\text { peptides can be analyzed (90\%) }\end{array}$ \\
\hline iTRAQ & Few thousand & Protein quantification & $\begin{array}{l}\text { Lengthy sample processing } \\
\text { separately }\end{array}$ \\
\hline MudPIT & Few thousand & $\begin{array}{l}\text { Protein identification and } \\
\text { quantification, no labeling }\end{array}$ & No quantitative analysis \\
\hline
\end{tabular}

Three methods have been developed to define $\mathrm{T}$ cell tumor antigens. First method is $\mathrm{T}$ cell epitope cloning. cDNA libraries generated from tumor cells are transfected into target cells expressing the appropriate MHC Class I or II molecules, and anti-tumor T cells are used to identify the appropriate transfectant $[6,9,131-134]$. This method is a labor-intensive process and requires $\mathrm{T}$ cell culture and cloning expertise. Second is HLA-binding peptide elution. Peptides are eluted from the surface of cancer cells (or from MHC Class I or II molecules purified from cancer cells), pulsed onto APC and tested for reactivity with the patient's lymphocytes. Purification and sequencing of these peptides identifies the parental protein [135-137]. This method requires protein chemistry expertise in peptide purification and high power mass spectrometry. A third approach consists in identifying a subcellular compartment containing the CD4+ $\mathrm{T}$ cell-stimulatory activity, followed by separation of the stimulatory protein fraction by reversed-phase high-performance liquid chromatography (RP-HPLC). The resulted fractions are then subjected by gel electrophoresis. The stimulatory band, identified by T-cell Western blotting, is finally subjected to protein sequencing [138].

A fourth method is to identify TAAs recognized by the antibody repertoire of cancer patients. These TAAs are overexpressed in patients and found at the surface of cells in peptide-MHC complex. TAAs identified with this method could be used for vaccination. In 1995, Pfreundschuh's team developed 
this method of serological cloning approach called SEREX [129,139-141], which allows a systemic and unbiased search for antibody responses against protein antigens expressed by human tumors. The development of SEREX offered a high-throughput approach to analyze the humoral response against TAAs in cancer patients. This has allowed the direct molecular identification of antigenic tumor proteins. The respective tumor antigens in the recombinant cDNA libraries are identified from their reactivity with antibodies in the autologous and allogeneic sera of cancer patients. The advantages of SEREX include rapid identification of multiple tumor antigens and no need for establishment of tumor cell lines and pre-established CTL clones [129]. SEREX remains the prominent technology for identifying TAAs that could be used for immunotherapy [142] or diagnosis and prognosis [143].

\subsection{Biomarkers}

\subsubsection{Sample choice and preparation}

Blood is the most commonly used biological fluid for biomarker analysis in clinical practice. The advantages of using blood, serum and plasma as a source to mine for biomarkers include that it can be obtained through a minimally invasive procedure, it is abundantly available and some constituents of blood reflect diverse pathological states. It is known that plasma proteins range in concentration over 12 orders of magnitude and that $99 \%$ of the protein mass is comprised of only 22 proteins. For example, the most abundant plasma protein is albumin, which is present in plasma at a concentration of $\sim 50 \mathrm{mg}$ per milliliter. In contrast, known cancer derived proteins in the circulation are present at a few nanograms per milliliter, 10 million times less abundant than albumin. This large dynamic range of analytes in blood is a major disadvantage for using this source for biomarker discovery. The removal of predominant proteins facilitates better detection of less abundant proteins, but such depletion can lead to the loss of informative molecules. Without fractionation, the complexity of serum and plasma is a limitation, and important biological information can be lost in the background noise [144]. Early experiments in proteomics profiling of serum and plasma made evident that there is no technology platform that can analyze proteins quantitatively with a dynamic range of concentration as high as $10^{12}$ [145] and that pre-fractionation of these samples is necessary [146,147]. Currently, the major objective of clinical proteomics utilizing body fluids is to reduce the dynamic range of proteins in analyzed samples [145,147]. Initially, columns and cartridges for albumin and IgG were available [148,149] and were soon followed by columns for multiple protein removal, based on immunodepletion [150]. In a relatively short period, removal of most abundant proteins from serum/plasma became a standard first step in clinical proteomics analyses aiming at biomarker discovery [151]. This widely-used approach is now commonly accepted as the first step in sample preparation and it is quite obvious that immunodepletion of the 12 most abundant proteins is necessary (i.e., albumin, $\operatorname{IgG}$, fibrinogen, transferrin, IgA, IgM, haptoglobin, apo A-I, apo A-II, a1-antitrypsin, a1-acid glycoprotein, a2-macroglobulin). These proteins comprise over $96 \%$ of total protein content in plasma/serum [145]. However, immunodepletion of multiple proteins can increase the risk of losing proteins of interest or low abundant candidate biomarkers that are removed along with those specifically depleted. Sample preparation remains one of the most time consuming and error prone aspects of analytical chemistry. 
Another source of sample is surgically-removed or biopsy-obtained tissues. They are currently being considered as alternative sources for biomarker discovery. One of the major advantages of using tissues is that the concentration of candidate biomarkers should be highest in tumor tissues and they should be a rich source for plasma biomarkers. Under this strategy, candidate biomarkers are first discovered in tumors and then subsequently measured out in the plasma using highly sensitive, targeted assay technologies. Tissues can be difficult to obtain in sufficient quantities, especially normal counterparts for comparative analyses. Alternatively, cancer cell lines can be analyzed. They are easy to handle and comprise a homogeneous and almost inexhaustible source of biological material, including proteins. However, each cell line represents only one tumor unaffected by signals from the microenvironment, and the cells may have been subjected to clonal drift and in vitro selection, which may render them less representative of the tumor from which they originated [152-154].

Plasma membrane proteins that are exposed on the cell surface have important biological functions, such as signaling into and out of the cells, ion transport, and cell-cell and cell-matrix interactions. The expression level of many of the plasma membrane proteins involved in these key functions is altered on cancer cells, and these proteins may also be subject to post-translational modification, such as altered phosphorylation and glycosylation. Additional protein alterations on cancer cells confer metastatic capacities, and some of these cell surface proteins have already been successfully targeted by protein drugs, such as mAbs. Because plasma membrane proteins are low-abundant proteins compared with many soluble proteins, the overall fraction of plasma membrane proteins in a cell/tissue lysate is very low, making them difficult to study, even with the recent advances in proteomics technologies [155-157]. The combination of novel analytical approaches and subcellular fractionation procedures has made it possible to study the plasma membrane proteome in more detail, which will elucidate cancer biology, particularly metastasis [158,159], and guide future development of novel drug targets.

There are different strategies of sample preparation based on depletion of highly abundant proteins or on sample fractionation. (1) Centrifugal ultrafiltration is a variation of membrane filtration in which centrifugation forces a liquid against a semi-permeable membrane. Suspended solids and solutes of high molecular weight are retained, while the liquid and low molecular weight solutes pass through the membrane depending on the molecular weight cut off of the membrane used [160,161]; (2) Solid phase extraction (SPE) is a separation technique that uses a solid phase to isolate one, or one type, of analyte from a solution. SPE is commonly used in serum/plasma samples as a clean-up step to remove highly abundant proteins. Solid phase extraction columns are probably the approach most widely used for depletion of high abundance proteins in serum/plasma. Different types of SPE columns based on ion-exchange [162-164], metal chelating, affinity ligands [165], dye-ligands [166-168], bacterial proteins $[169,170]$, antibodies $[165,171]$ or combinations of these have been used. Surface-enhanced laser desorption/ionization (SELDI) is an affinity-based mass spectrometric method that combines sample fractionation with mass spectrometry (MS) analysis. In recent decades, magnetic beads have emerged as a promising new platform in biomedical applications, particularly bioseparations [172]. Functionalized magnetic beads are used for solid phase extraction of a specific subset of molecules from a liquid. The nature of the molecules retained depends directly on the kind of surface-derivatized beads used; (3) The third method is organic solvent extraction. The possibility of selectively removing large abundant proteins from serum by precipitating them with simultaneous extraction of peptides and 
low molecular weight proteins using organic solvents has been tested [173]. The precipitation with organic solvents in the presence of ion-pairing agents dissociates peptides and smaller proteins from large abundant proteins, thereby facilitating their extraction. Other strategies consist of sample fractionation before analysis by MS such as electrophoresis and chromatographic processes could be considered as sample preparation but also analysis strategies. These methods will be described later in the review. For enrichment of plasma membrane proteins, most strategies used either homogenization followed by membrane density separation or whole cell protein tagging followed by affinity purification. Enrichment of plasma membrane proteins using whole cell protein tagging is often based on a membrane-impermeable biotin labeling reagent followed by cell lysis and affinity purification using streptavidin-coated beads [174-176].

\subsubsection{Gene expression profiling}

In the late 1990s, DNA microarray technology emerged as a powerful tool for the analysis of the levels of mRNA transcripts expressed under various conditions. For example, microarray technology has been used to compare gene expression profiles in ovarian cancers and normal ovaries. The aim is to identify genes that are differentially expressed between the two states, with the expectation that similar patterns could be seen for the respective proteins in serum [177]. Several studies have attempted to identify new molecular biomarkers for the early detection of ovarian cancer by gene expression profiling [178-180]. The advantages of this approach include high throughput and objective molecular subclassification. Gene expression levels reflect the cumulative effect of several underlying biological functions as DNA-microarray technology has enabled the simultaneous examination of thousands of genes, in contrast to studying the expression of single genes. Current microarray platforms are highly automated and enable parallel sample analysis. Although information on mRNA expression levels and the corresponding protein abundances (or activities) are undoubtedly useful in genomic analyses, their values do not always correlate. Furthermore, the analysis of mRNA transcripts does not provide information regarding post-translational modifications (e.g., proteolysis, phosphorylation, glycosylation, acetylation, and deamination) of target proteins. Thus, alternative analytical methods are necessary for extended proteome studies.

\subsubsection{Mass spectrometry}

For protein quantification, the most commonly used method has been the ELISA [181] (Table 5). Due to its sensitivity and reliability, this method is widely used both in biomedical research and clinical diagnostics of proteins. Another important method, immunohistochemistry (IHC) is capable of localizing proteins of interest within a cell or tissue utilizing specific visualization techniques, such as fluorescently labeled antibodies [182]. However, this method is not able to quantify the exact amount of the proteins, but multispectral imaging does allow the examination of different proteins in a single measurement. However, these procedures are not applicable for target discovery principally due to the low throughput of the methods and the necessity of large volume of sample (Table 5). For this reason, MS-based protein identification combined with quantitative measurements is at the center of development of new technologies and methods. In MS, proteins are digested to predictable peptide fragments using proteases such as trypsin. Tryptic digests of biological proteomes (e.g., tissue or 
plasma-derived proteins) can be analyzed using different modes of MS, depending on the desired application. For example, untargeted modes of mass spectrometry are used for de novo discovery of biomarker candidates such as from tumor tissues or proximal fluids. In contrast, targeted modes of mass spectrometry allow us to look for peptides (and so proteins) of interest in clinical specimens (SILAC, iTRAQ, ICAT, see later in this review). These modes of mass spectrometry can be very useful for determining whether biomarker candidates discovered in tissues or proximal fluids are present (and elevated) in plasma from cancer patients compared to controls. Moreover, all these techniques appear to be complementary and not exclusive. Mass spectrometers consist of an ionization source, a mass analyzer, and a detector. Although there are a variety of ionization sources (e.g., electrospray and matrix assisted laser desorption ionization) and mass analyzers, all MS instruments have these basic features in common. In a typical analysis of a biological sample, proteins or peptides are introduced into the ionization source where they are converted to gas-phase charged particles (ionized) and passed to the mass analyzer. In the mass analyzer, the ions are separated (using electric and magnetic fields) based on their mass-to-charge $(\mathrm{m} / \mathrm{z})$ ratios. The detector electrically detects the beam of ions passing through the machine (i.e., the ion current) and amplifies the signal, which is recorded in the form of a mass spectrum. The fragmentation pattern is compared to the theoretical fragmentation pattern for every peptide in the genome to find the closest match. In this way the sequence of the peptide ion is inferred from its fragmentation pattern.

\subsubsection{Two-dimensional electrophoresis}

Electrophoresis is the movement of charged particles through a medium by using an electric field induced by electrodes. In proteomics, electrophoresis, especially gel electrophoresis, is still the most used separation technique for complex protein mixtures. Gel electrophoresis refers to the technique in which molecules are forced across a span of gel motivated by an electrical current. Activated electrodes at either end of the gel provide the driving force. The properties of the molecules, such as size, electric charge, structure, etc. determine how rapidly an electric field can move them through the gel. 2D-PAGE is widely used in proteomic studies due to its separation power. Proteins are initially separated according to their isoelectric point (pI) by isoelectric focusin (IEF) in the first dimension, followed by separation in the second dimension according to their molecular weight. The result is an array of spots detected by different staining procedures [183]. Up until now 2D-PAGE has been primarily utilized to analyze complex protein mixtures in most laboratories [122,123]. This method allows comparative studies of different samples, such as normal versus diseased, or treated versus untreated, in order to determine expressional differences at the individual protein or protein group level, assumed to be responsible for phenotype changes (Table 5). 2D-PAGE is the most widely used proteomics technique to study the proteome as well as cancer biomarkers [184-188]. In a proteomics study of breast cancer serum, two proteins, hsp27 (up-regulated) and 14-3-3 sigma (downregulated) were identified using 2D-PAGE coupled with MALDI-TOF-MS [189]. Another example is identification of potential serum markers in pancreatic cancer. Serum samples from 3 pancreatic cancer patients and 3 normal and healthy individuals were analyzed using two dimensional differential gel electrophoresis (DIGE) coupled with MALDI/TOF/TOF-MS and 24 unique up-regulated proteins and 17 unique downregulated proteins were identified in cancer serum [188]. To identify the proteins of 
interest, other downstream processes such as Western blotting and/or MS is applied. The resolution of this method is sufficient to separate protein isoforms modified by post-translational processes. However, this approach has several limitations: (a) Difficulty with automation; (b) Poor detection of low-abundance proteins; (c) Difficulty in separating hydrophobic membrane proteins, and basic and high molecular mass proteins; (d) Poor reproducibility; and (e) Time-consuming protocols. Modified 2D electrophoresis by fluorescent tagging of proteins (DIGE), offers increased throughput, ease of use, reproducibility, and accurate quantitation of protein expression differences [190]. This system enables the separation of two or three fluorescently labeled protein samples (Cy2, Cy3 and Cy5) on the same gel.

\subsubsection{Chromatographic processes}

Chromatographic processes can be defined as separation techniques involving mass-transfer between stationary and mobile phases. Liquid chromatography (LC) is the most widely used mode of analytical chromatography and uses a liquid mobile phase to separate the components of a mixture. These components (or analytes) are present in a liquid phase or dissolved in a solvent, and then forced to flow through a chromatographic column usually under high pressure (HPLC). In the column, the mixture is resolved into its components. As a result, LC acquires a high degree of versatility not found in other chromatographic systems and it has the ability to easily separate a wide variety of chemical mixtures. Application of LC-MS to biomarker discovery is not yet very widespread partly because the method generates large and highly complex data sets that require powerful algorithms and software tools to handle and analyze them.

\subsubsection{SELDI-TOF MS}

SELDI-TOF MS, introduced in 1998 by Ciphergen [191] is an innovative microarray approach, and offers on-chip purification of unlabeled target proteins followed by subsequent ionization and MS detection of the retained molecules [192]. This technique allows proteins/peptides to be profiled from different biological samples on a variety of chemically (e.g., anionic, cationic, hydrophobic, hydrophilic, metal affinity capture) or biochemically (e.g., immobilized antibody, receptor, DNA, enzyme) defined chromatographic surfaces (Table 5). A small amount of sample of interest is loaded onto ProteinChip ${ }^{\mathrm{TM}}$ arrays that selectively bind different subsets of proteins in crude samples by adsorption, partition, electrostatic interaction or affinity chromatography according to their surface chemistries. After a short incubation period, unbound proteins and unspecific substances are washed away with an appropriate buffer and water. The ToF reader records the time-of-flight and calculates the accurate molecular weight of proteins/peptides in the form of a spectral map containing mass to charge ratios $(\mathrm{m} / \mathrm{z})$ and intensities corresponding to each bound protein/peptide. For example, applications of SELDI-ToF have been demonstrated for the early detection of prostrate $[193,194]$, breast [195,196] and pancreatic [197] cancer biomarkers. SELDI was also used in the discovery and detection of a number of cancer-associated biomarkers, including those for ovarian cancer [198], prostate cancer [199] and breast cancer [200]. However, there is some controversy over this technology such as its reproducibility, the bioinformatics used, the possibility of over-fitting, the potential bias in the samples, as well as how this could possibly fit into a routine diagnostic lab [201,202]. 


\subsubsection{Laser capture microdissection}

Analysis of human tissue is essential for translational research because cell cultures and even animal carcinogenesis models may not accurately represent the complexities of human disease states [203]. Laser capture microdissection allows scientists to procure pure cell populations from heterogeneous tissue sections [204,205]. Protein or DNA/RNA may be analyzed from the microdissected cells, lending this technology to comprehensive molecular profiling of tissues.

Laser-capture microdissection, described by Emmert-Buck et al. in 1996 brings molecular analysis to the cellular level [204]. This technique allows for precise collection of pure cell populations. Studies have confirmed that microdissection increases the specificity of signals obtained in downstream protein analysis [206-209]. Laser-capture microdissection is particularly vital in the molecular profiling of normal and malignant tissue because of its utility in obtaining pure cell populations.

\subsubsection{Proteins quantification}

Because most disease associated markers are not exclusively expressed in either the disease or the "healthy" state, quantification of protein expression differences must be included in marker identification strategies. The quantification strategies used in combination with MS based proteomics are often based on the introduction of stable isotopes into the samples, which can be done either by metabolic, chemical, or proteolytic labeling (Table 5).

SILAC: The most widely used metabolic labeling strategy is stable isotope labeling by amino acids in cell culture (SILAC). SILAC is simple and powerful because the label is introduced prior to protein purification but can mainly be applied to cells in culture. Quantitative proteomics using chemical and proteolytic labels is, in contrast to SILAC, sensitive to variations in protein purifications between the compared samples because the labels are introduced after protein purification.

ICAT: Isotope-coded affinity tags (ICAT) use stable isotope labeling to perform quantitative analysis of paired protein samples. It consists of a reactive group, which reacts with cysteine residues, a linker containing the stable isotopes and a biotin tag for purification of labeled peptides [210]. Both samples are mixed, digested with trypsin, fractionated by avidin affinity chromatography and then these differentially tagged peptides are scanned in a mass spectrometer. Spectral peak analysis in single mass spectrometric (MS) mode of the isotopically resolved peptides from the two different sources enables quantitation of the relative amounts of the peptide and hence the protein levels. One weakness of ICAT is that only cysteine containing peptides can be labeled. Approximately $10 \%$ of proteins do not have cysteine, therefore they will not be detected by ICAT.

iTRAQ: In the iTRAQ system, the tags react with the $\mathrm{N}$ termini of the peptide and lysine residues, thus tagging all peptides [211]. iTRAQ contains a set of four isobaric reagents and therefore can analyze up to four protein samples at one time. After trypsin digestion, samples are labeled with four independent iTRAQ reagents and analyzed by MS. The intensity of each of these peaks represents the quantity of small reporter group fragments and thus represents the quantity of a peptide sample. Peaks in the spectrum graph are used to identify peptide sequences and therefore protein sequences. A comparative analysis of iTRAQ and ICAT suggests that the information generated by the two methods is complementary. ICAT is preferred for low abundant proteins including signaling molecules; 
however, overlapping peaks in the MS spectrum can compromise the quality of results. On the other hand, apart from nonspecific nature of labeling, iTRAQ requires lengthy sample processing separately that increases the chances of experimental variation [212].

${ }^{18} \mathrm{O}$ : Heavy oxygen $\left({ }^{18} \mathrm{O}\right)$ can be introduced into peptides through proteolytic labeling by digesting the proteins in the presence of $\mathrm{H}_{2}{ }^{18} \mathrm{O}$ using trypsin, Lys-C, or Glu-C, which introduces one or two ${ }^{18} \mathrm{O}$ molecules into the peptides [213].

MudPIT: MudPIT is an approach that uses multidimensional high-pressure liquid chromatography separation, tandem mass spectrometry and database searching [214]. MudPIT permits a rapid and simultaneous separation and identification of proteins and peptides in a complex mixture without the need for pre- or post-separation labeling, which is not possible in ICAT or iTRAQ [215]. The complex protein mixture is digested with a specific protease, peptide fragments are separated in parallel by two dimensional liquid chromatography (strong cation exchange column and reverse phase column). Eluted peptides are identified by tandem mass spectrometry. The technique is extremely sensitive and reproducible. One of the major weaknesses of MudPIT is in identifying quantitative differences in protein expression across protein mixtures [216].

\subsubsection{Immuno-enrichment}

The most selective and sensitive methods for the enrichment of low abundant analytes in proteome analyses use highly selective capture molecules. Immunoprecipitation, co-immunoprecipitation or pull-down assays have been set up to enrich single proteins or protein complexes from highly complex samples followed by direct MS-based quantification or by proteolytic cleavage and identification of peptides via peptide mass fingerprint or MS/MS-based methods [217-220]. Other approaches use antibody phage display technology which is a strategy used to isolate tumor specific antibodies able to bind their cognate antigens in the cellular context for therapeutic uses [221-224]. For antibody phage display, antibody fragments are fused to the pIII minor capsid protein and displayed at the surface of filamentous phage M13. Repertoires of antibody variable (V) domains can be generated and used to construct large libraries of human scFv, Fab, or single domain antibody, which can then be used to generate panels of antibodies to virtually any antigen [225,226]. Direct selection of tumor specific antibodies from phage display human antibody libraries on tumor cells provides an approach for generating large panels of human antibodies that recognize tumor specific markers [225,227-231]. These tumor specific antibodies can be used to immunoprecipitate their tumor antigen for identification by MS, allowing a reduction of the sample complexity before MS based protein identification.

\subsubsection{Protein array}

In a basic sense, protein arrays consist of immobilized protein in a defined area. Protein microarrays were first described by MacBeath and Schreiber in 2000, and the number of publications involving this technology is rapidly increasing [232]. Miniaturized microspot assays are becoming increasingly popular for protein-protein interaction analysis and protein profiling. Each array spot contains homogeneous or heterogeneous capture agents such as antibodies [233-235], aptamers, recombinant proteins or peptides [232,236], cell or phage lysates [237], or drugs immobilized at high spatial density on a solid surface to selectively extract target proteins from complex mixtures, including serum and 
cell lysate samples. They are the protein analog of cDNA arrays. However, they are technically more difficult to make because proteins are more complex in their composition, protein folding, denaturation, aggregation, and multimerization. Protein-detecting microarrays are typically used for two different types of analysis: (a) Determining the abundances of target proteins in a complex mixture through highly specific antigen-antibody interactions [238]; and (b) Providing information on the functions of target proteins through protein-protein interactions, receptor-ligand interactions, enzymatic activities, and other methods [239-245]. Protein arrays are being used for drug discovery, biomarker identification and molecular profiling of cellular material [236,246-248]. There are currently two classes of protein microarrays used in human sample research: Forward-phase protein microarrays (FPPAs) and reverse-phase protein microarrays (RPPAs) (Table 5).

FPPA: Forward-phase arrays use immobilized antibodies as bait to capture specific antigens within a heterogeneous mixture. As bait antibodies incubate with a test sample, antigens of interest become bound to their corresponding antibodies. The antigens of interest are then detected and visualized by a second "sandwich" antibody. The disadvantage of FPPAs is the requirement for 2 antibodies for the identification of any particular antigen. Therefore, the antigens of interest must be in conformational states allowing the binding of two distinct antibodies.

The most commonly used microchips are planar antibody microarrays, where well-characterized antibodies are immobilized to capture the proteins of interest. The wider application of protein arrays in biomedical research is still limited, partly because of the cost of producing and immobilizing antibodies and the limited availability of antibodies with high specificity and high affinity for their target. Recently, new strategies have been developed to solve these problems such as the use of very stable and available single domain antibodies (sdAb) [249]. Additionally, the difficulties associated with preserving proteins in their biologically active conformation before analysis with protein arrays further limits the application of this technology as a routine proteomic strategy. Nevertheless, protein-array platforms became an attractive profiling approach among many proteomics technologies [245,250-253] because of the promise of large scale analysis that can be performed with relatively low amount of sample, technical ease and high throughput [254,255]. Microbead-based protein arrays are based on the interaction between surface (polystyrene microspheres) attached capture molecules and proteins of cell lysates. The surface bound complexes on the microbeads are interrogated by flow cytometry. This technique is suitable to detect protein-protein, nucleic acid-protein, and nucleic acid-nucleic acid interactions. Multiplexing is achieved by either using different sized microbeads or color coding that is readable by a laser-induced fluorescent detection system [256]. This latter approach is suitable for the analysis of up to a hundred different bead-bound antibodies and/or proteins in a complex mixture.

$\underline{R P P A}$ : Reverse-phase protein microarrays have been introduced by Paweletz et al. in 1998 [257]. The name "reverse-phase" is used because cell lysates are immobilized in the solid phase and are probed with an antibody. An array can be composed of many patient samples in a dilution curve format that allow quantitation [258]. Moreover, multiple lysates representing normal invasive cell populations may be printed in parallel on the same array. There are many advantages of reverse-phase protein arrays to analyze cancer-related protein networks. First, RPPAs have higher throughput capabilities. Reverse-phase protein microarrays require low sample volume (approximately $2 \mathrm{~nL}$ per spot), enabling researchers to print hundreds of patient samples onto a single array slide. In addition, 
the low volume requirement allows for analysis of often-limited patient biopsy material. The high-throughput nature of RPPAs is also necessary for the real-time analysis of patient tissue.

NAPPA: The next advancement in protein microarrays was development of high-density, self-assembling protein microarrays, based on the concept of the nucleic-acid programmable protein array (NAPPA) [251,252,254]. The concept is to synthesize proteins on the high-density chip using spotted cDNA and a T7-coupled rabbit reticulocyte lysate in vitro transcription-translation (IVTT) system [251]. Translated proteins contain a C-terminal glutathione S-transferase (GST) tag, which is used to capture co-printed anti-GST antibody. NAPPA represents a crucial step in addressing many of the concerns related to manufacturing limitations (e.g., density of printing, reproducibility, and quality of immobilized proteins).

To resume, microarrays are useful for high throughput analysis of candidate biomarkers in patient samples. However, the method has a limited role in discovery based identification of novel biomarkers where other platforms, such as MS, are better suited. Despite the technological advances, protein microarrays still suffer from skepticism and criticism. At present, protein arrays remain an emerging technology $[259,260]$ that requires further technological developments and refinements but have great potential as complementary approaches to other profiling platforms.

\subsubsection{Surface plasmon resonance}

Surface plasmon resonance (SPR) is one of the most sophisticated methods used today to detect and quantify biomolecular interactions in real time in a nondestructive manner without any labeling requirement [261] (Table 5). Capture agents are immobilized on a gold surface, and the change in the reflection angle of light is used to quantify the number of unlabeled target molecules captured on the surface [262]. In conventional SPR systems, a single channel is available within a single experiment. Thus, miniaturization and parallelization of SPR apparatus have been elaborated to perform multiple measurements in a single experiment. Recently, a SPR imaging technique was developed to improve throughput in SPR-based detection of molecular interactions. For instance, the S-protein-S-peptide interaction was examined using an array composed of five different peptides, including S-peptide, by determining an association rate, a dissociation rate, and an equilibrium association constant [263]. SPR imaging methods can now monitor hundreds of biomolecular interactions in real time simultaneously, and are suitable for unqualitative screening and quantitative kinetics experiments [264]. The integration of SPR and MS has proven useful in the analysis of biomolecular interaction patterns, including drug candidates, enzyme inhibitors, DNA binding proteins, disease markers, peptide sequences, and post-translational modification [265-268].

\subsubsection{Tissue microarray}

Tissue microarray (TMA) technology was first described by Wan et al. in 1987 [269]. However, it was not until 10 years later, when Kononen et al. developed a device that could rapidly and reproducibly produce quality TMAs [240] that this technique emerged. The key benefit underlying TMA technology is the ability to assay hundreds of patient tissues arrayed on a single microscope slide. In its most common form, a core of tissue is lifted from a formalin-fixed, paraffin embedded sample and placed in a predrilled hole in a paraffin recipient block. On sectioning, each sample is 
represented as a small (0.6- to 2-mm diameter) histologic section arrayed in a grid that allows easy linkage to clinicopathologic data. The result is a single slide that contains samples from 40 to 800 patients (depending on core size). Other researchers have adapted TMA technology to frozen tissues [270], cell lines [271,272], and needle biopsies [273]. TMA provide several benefits. Each TMA uses only a small core from the donor blocks, each block can be used in dozens (or potentially hundreds) of newly created TMAs. Second, TMAs can drive significant cost savings both in terms of reagents and technician time required to stain one slide instead of hundreds. Third, because of the inherent efficiency in processing hundreds to thousands of tumors at one time, TMAs can dramatically increase the number of tumors that can be analyzed compared with traditional whole-section studies. TMAs are arrayed on a single slide, all of the tumor specimens are stained consistently, at the same time, under the same conditions, and with exactly the same antibody dilution. However, because TMAs examine only a fraction of the tumor that is analyzed using traditional methods, many researchers were initially concerned that TMA cores would not adequately assess biomarkers that exhibited tissue heterogeneity. Subsequently, multiple groups have demonstrated strong correlations between TMA histospots and whole-tissue sections [274,275]. Although the size of TMA histospots presented challenges to assessing tumor heterogeneity, they also provided a new opportunity for developing automated methods of analysis. Indeed, histospots are sufficiently small to allow a rigorous molecular quantification. Because TMAs are prevalidated by a pathologist during construction, automated systems would only have to assess staining intensity. Automated analysis permits the quantification of biomarkers in a way that matches their biologic expression. The last 10 years have provided an opportunity to invent and refine new techniques in production, staining, and analysis that will help TMA technology with the big challenge of discovery of biomarkers. TMAs are ideally suited to rapidly triage hundreds or thousands of potential biomarkers, permitting researchers to focus on a few likely candidates [276]. It has become an attractive validation strategy and is also sometimes described as a proteomics technique. This type of validation of potential novel biomarkers, including PM proteins, relies on access to large numbers of biological samples, e.g., biopsies of primary tumors and metastases collected and stored for research at hospitals.

\subsection{Glycosylated Proteins}

Glycosylation is the most common, being present in $\sim 50 \%$ of the total number of proteins [65]. Cancer cells frequently display glycoproteins with increased branching of the glycan structures and/or altered expression levels compared with normal cells [82]. An increase in the branching creates additional sites for terminal sialic acid residues, negatively charged acidic sugars that can be recognized by lectins [277]. The glycan structure or expression level of many PM glycoproteins may be altered, alterations may also occur on secreted glycoproteins and serve as biomarkers for early detection of cancers [82,278-280]. Tumor markers in current clinical use, such as carcinoembryonic antigen, prostate-specific antigen, HER-2, and mucins (e.g., CA 19.9, CA 125, and CA 15.3), are all glycoproteins that are either membrane-associated or secreted to the serum [280-282].

Glycoproteomics usually includes enzymatic digestion of the glycoprotein-containing samples to generate peptides and glycopeptides. The glycopeptides are then enriched using selective chromatographic methods, typically using immobilized lectins, hydrophilic interaction LC, titanium 
dioxide, or graphite [283-291]. Lectins, e.g., concanavalin A, differ in their specificity and selectivity toward glycan compositions. The glycopeptides recovered by one or a combination of enrichment methods are then analyzed using MS, which can be used to obtain spectra of intact glycoproteins, glycopeptides, or released glycans [140,292]. The challenge with quantitative and qualitative analysis of glycopeptides is that it is not always possible to obtain glycopeptides with just one glycosylation site, and not all glycosylation sites are necessarily occupied by glycan moieties, whereas others may be partially occupied. Exploiting differences in glycosylation between malignant and healthy tissues likely affords excellent opportunities to identify sensitive and specific cancer biomarkers [92,284,293].

\section{Conclusions}

Application of genomic and proteomic technologies have led to the identification of many hundreds to thousands of biomarker candidates for several diseases. The identification and characterization of tumor specific markers remains a major goal in both understanding the cellular transformation observed in cancer and in developing targets for the molecular therapy of cancer. Molecules that are tumor-specific or overexpressed in cancer are likely to have functional roles that participate in cellular transformation and migration. Targeting of such molecules can result in an anti-tumor effect and therefore might be of interest for cancer therapy. Of particular interest within the spectrum of tumorspecific and overexpressed molecules are those located at the cell surface, since they are readily accessible and can be used to target cancer cells with highly specific ligands like mAbs. A difficulty of protein expression profiling arises from the unpredictable rate of protein degradation. Proteins act mostly as effector molecules with a short life time and their degradation is influenced by many parameters such as size, structure, composition, co- and post-translational modifications, etc. Changes can also be caused by an altered reaction environment such as $\mathrm{pH}$, salt concentration, hydrophobicity, or by analysis-related artifacts that are generated during sample processing.

New challenges arise in large scale proteomic profiling when dealing with complex biological mixtures such as mammalian cell lysate. Identification of large numbers of proteins from complex biological samples is a continuing challenge in the area of quantitative proteomics. However, the sample complexity can be effectively reduced with corresponding increases in protein identification using various methods. In the near future, the refinement and possible combination of these emerging techniques will likely lead to the identification of a large panel of new biomarkers and tumor antigens. Hopefully these new markers will then be used to develop efficient diagnostic procedures and relevant immunotherapeutic approaches against a large variety of cancers.

\section{Acknowledgements}

This work was supported by CNRS, INSERM, the French National Research Agency (Agence Nationale de Recherche-ANR) program 'Nanosciences and Nanotechnologies' under the grant ANR-07-PNANO-051-01 and by the ARC (Association pour la Recherche contre le Cancer).

\section{References}

1. Bergman, P.J. Cancer immunotherapy. Vet. Clin. North Am. Small Anim. Pract. 2010, 40, 507-518. 
2. Weiner, L.M.; Surana, R.; Wang, S. Monoclonal antibodies: Versatile platforms for cancer immunotherapy. Nat. Rev. Immunol. 2010, 10, 317-327.

3. Vergati, M.; Intrivici, C.; Huen, N.Y.; Schlom, J.; Tsang, K.Y. Strategies for cancer vaccine development. J. Biomed. Biotechnol. 2010, doi:10.1155/2010/596432.

4. Higano, C.S.; Schellhammer, P.F.; Small, E.J.; Burch, P.A.; Nemunaitis, J.; Yuh, L.; Provost, N.; Frohlich, M.W. Integrated data from 2 randomized, double-blind, placebo-controlled, phase 3 trials of active cellular immunotherapy with sipuleucel-T in advanced prostate cancer. Cancer 2009, 115, 3670-3679.

5. Small, E.J.; Schellhammer, P.F.; Higano, C.S.; Redfern, C.H.; Nemunaitis, J.J.; Valone, F.H.; Verjee, S.S.; Jones, L.A.; Hershberg, R.M. Placebo-controlled phase III trial of immunologic therapy with sipuleucel-T (APC8015) in patients with metastatic, asymptomatic hormone refractory prostate cancer. J. Clin. Oncol. 2006, 24, 3089-3094.

6. van der Bruggen, P.; Traversari, C.; Chomez, P.; Lurquin, C.; De Plaen, E.; Van den Eynde, B.; Knuth, A.; Boon, T. A gene encoding an antigen recognized by cytolytic $\mathrm{T}$ lymphocytes on a human melanoma. Science 1991, 254, 1643-1647.

7. Traversari, C.; van der Bruggen, P.; Luescher, I.F.; Lurquin, C.; Chomez, P.; Van Pel, A.; De Plaen, E.; Amar-Costesec, A.; Boon, T. A nonapeptide encoded by human gene MAGE-1 is recognized on HLA-A1 by cytolytic T lymphocytes directed against tumor antigen MZ2-E. $J$. Exp. Med. 1992, 176, 1453-1457.

8. Dermime, S.; Gilham, D.E.; Shaw, D.M.; Davidson, E.J.; Meziane el, K.; Armstrong, A.; Hawkins, R.E.; Stern, P.L. Vaccine and antibody-directed T cell tumour immunotherapy. Biochim. Biophys. Acta 2004, 1704, 11-35.

9. Boon, T.; van der Bruggen, P. Human tumor antigens recognized by T lymphocytes. J. Exp. Med. 1996, 183, 725-729.

10. Mathieu, M.G.; Miles, A.K.; Li, G.; McArdle, S.E.; Rees, R.C. Cancer/testis antigens for therapeutic use. J. BUON 2009, 14 (Suppl. 1), S97-S102.

11. Chen, Y.T.; Old, L.J. Cancer-testis antigens: Targets for cancer immunotherapy. Cancer J. Sci. Am. 1999, 5, 16-17.

12. Fijak, M.; Meinhardt, A. The testis in immune privilege. Immunol. Rev. 2006, 213, 66-81.

13. Ribas, A.; Weber, J.S.; Chmielowski, B.; Comin-Anduix, B.; Lu, D.; Douek, M.; Ragavendra, N.; Raman, S.; Seja, E.; Rosario, D.; et al. Intra-lymph node prime-boost vaccination against melan A and tyrosinase for the treatment of metastatic melanoma: Results of a phase 1 clinical trial. Clin. Cancer Res. 2011, 17, 2987.

14. van Meerten, T.; Hagenbeek, A. CD20-targeted therapy: The next generation of antibodies. Semin. Hematol. 2010, 47, 199-210.

15. Elkord, E.; Burt, D.J.; Drijfhout, J.W.; Hawkins, R.E.; Stern, P.L. CD4+ T-cell recognition of human 5T4 oncofoetal antigen: Implications for initial depletion of CD25+ T cells. Cancer Immunol. Immunother. 2008, 57, 833-847.

16. Carballido, E.; Fishman, M. Sipuleucel-T: Prototype for development of anti-tumor vaccines. Curr. Oncol. Rep. 2011, 13, 112-119.

17. Singh, R.; Bandyopadhyay, D. MUC1: A target molecule for cancer therapy. Cancer Biol. Ther. 2007, 6, 481-486. 
18. Ghosh, A.; Heston, W.D. Tumor target prostate specific membrane antigen (PSMA) and its regulation in prostate cancer. J. Cell. Biochem. 2004, 91, 528-539.

19. Correa, I.; Plunkett, T. Update on HER-2 as a target for cancer therapy: HER2/neu peptides as tumour vaccines for T cell recognition. Breast Cancer Res. 2001, 3, 399-403.

20. Cloosen, S.; Arnold, J.; Thio, M.; Bos, G.M.; Kyewski, B.; Germeraad, W.T. Expression of tumor-associated differentiation antigens, MUC1 glycoforms and CEA, in human thymic epithelial cells: Implications for self-tolerance and tumor therapy. Cancer Res. 2007, 67, 3919-3926.

21. Yu, Z.; Theoret, M.R.; Touloukian, C.E.; Surman, D.R.; Garman, S.C.; Feigenbaum, L.; Baxter, T.K.; Baker, B.M.; Restifo, N.P. Poor immunogenicity of a self/tumor antigen derives from peptide-MHC-I instability and is independent of tolerance. J. Clin. Invest. 2004, 114, 551-559.

22. Gilboa, E. The risk of autoimmunity associated with tumor immunotherapy. Nat. Immunol. 2001, 2, 789-792.

23. Ludewig, B.; Ochsenbein, A.F.; Odermatt, B.; Paulin, D.; Hengartner, H.; Zinkernagel, R.M. Immunotherapy with dendritic cells directed against tumor antigens shared with normal host cells results in severe autoimmune disease. J. Exp. Med. 2000, 191, 795-804.

24. Tomlinson, I.; Sasieni, P.; Bodmer, W. How many mutations in a cancer? Am. J. Pathol. 2002, 160, 755-758.

25. Weir, B.A.; Woo, M.S.; Getz, G.; Perner, S.; Ding, L.; Beroukhim, R.; Lin, W.M.; Province, M.A.; Kraja, A.; Johnson, L.A.; et al. Characterizing the cancer genome in lung adenocarcinoma. Nature 2007, 450, 893-898.

26. Wood, L.D.; Parsons, D.W.; Jones, S.; Lin, J.; Sjoblom, T.; Leary, R.J.; Shen, D.; Boca, S.M.; Barber, T.; Ptak, J.; et al. The genomic landscapes of human breast and colorectal cancers. Science 2007, 318, 1108-1113.

27. Speetjens, F.M.; Kuppen, P.J.; Welters, M.J.; Essahsah, F.; Voet van den Brink, A.M.; Lantrua, M.G.; Valentijn, A.R.; Oostendorp, J.; Fathers, L.M.; Nijman, H.W.; et al. Induction of p53-specific immunity by a p53 synthetic long peptide vaccine in patients treated for metastatic colorectal cancer. Clin. Cancer Res. 2009, 15, 1086-1095.

28. Lauwen, M.M.; Zwaveling, S.; de Quartel, L.; Ferreira Mota, S.C.; Grashorn, J.A.; Melief, C.J.; van der Burg, S.H.; Offringa, R. Self-tolerance does not restrict the CD4+ T-helper response against the p53 tumor antigen. Cancer Res. 2008, 68, 893-900.

29. Hollstein, M.; Sidransky, D.; Vogelstein, B.; Harris, C.C. p53 mutations in human cancers. Science 1991, 253, 49-53.

30. Takenoyama, M.; Baurain, J.F.; Yasuda, M.; So, T.; Sugaya, M.; Hanagiri, T.; Sugio, K.; Yasumoto, K.; Boon, T.; Coulie, P.G. A point mutation in the NFYC gene generates an antigenic peptide recognized by autologous cytolytic $\mathrm{T}$ lymphocytes on a human squamous cell lung carcinoma. Int. J. Cancer 2006, 118, 1992-1997.

31. Chames, P.; Van Regenmortel, M.; Weiss, E.; Baty, D. Therapeutic antibodies: Successes, limitations and hopes for the future. Br. J. Pharmacol. 2009, 157, 220-233.

32. Carter, P.; Smith, L.; Ryan, M. Identification and validation of cell surface antigens for antibody targeting in oncology. Endocr. Relat. Cancer 2004, 11, 659-687.

33. Reichert, J.M.; Valge-Archer, V.E. Development trends for monoclonal antibody cancer therapeutics. Nat. Rev. Drug Discov. 2007, 6, 349-356. 
34. Palena, C.; Abrams, S.I.; Schlom, J.; Hodge, J.W. Cancer vaccines: Preclinical studies and novel strategies. Adv. Cancer Res. 2006, 95, 115-145.

35. Kass, E.; Schlom, J.; Thompson, J.; Guadagni, F.; Graziano, P.; Greiner, J.W. Induction of protective host immunity to carcinoembryonic antigen (CEA), a self-antigen in CEA transgenic mice, by immunizing with a recombinant vaccinia-CEA virus. Cancer Res. 1999, 59, 676-683.

36. Halabi, S.; Small, E.J.; Kantoff, P.W.; Kattan, M.W.; Kaplan, E.B.; Dawson, N.A.; Levine, E.G.; Blumenstein, B.A.; Vogelzang, N.J. Prognostic model for predicting survival in men with hormone-refractory metastatic prostate cancer. J. Clin. Oncol. 2003, 21, 1232-1237.

37. Kantoff, P.W.; Schuetz, T.J.; Blumenstein, B.A.; Glode, L.M.; Bilhartz, D.L.; Wyand, M.; Manson, K.; Panicali, D.L.; Laus, R.; Schlom, J.; et al. Overall survival analysis of a phase II randomized controlled trial of a Poxviral-based PSA-targeted immunotherapy in metastatic castration-resistant prostate cancer. J. Clin. Oncol. 2010, 28, 1099-1105.

38. Terasawa, H.; Tsang, K.Y.; Gulley, J.; Arlen, P.; Schlom, J. Identification and characterization of a human agonist cytotoxic T-lymphocyte epitope of human prostate-specific antigen. Clin. Cancer Res. 2002, 8, 41-53.

39. Madan, R.A.; Arlen, P.M.; Mohebtash, M.; Hodge, J.W.; Gulley, J.L. Prostvac-VF: A vectorbased vaccine targeting PSA in prostate cancer. Expert Opin. Investig. Drugs 2009, 18, 1001-1011.

40. Goldman, B.; DeFrancesco, L. The cancer vaccine roller coaster. Nat. Biotechnol. 2009, 27, 129-139.

41. Tsang, K.Y.; Palena, C.; Gulley, J.; Arlen, P.; Schlom, J. A human cytotoxic T-lymphocyte epitope and its agonist epitope from the nonvariable number of tandem repeat sequence of MUC-1. Clin. Cancer Res. 2004, 10, 2139-2149.

42. Zaremba, S.; Barzaga, E.; Zhu, M.; Soares, N.; Tsang, K.Y.; Schlom, J. Identification of an enhancer agonist cytotoxic T lymphocyte peptide from human carcinoembryonic antigen. Cancer Res. 1997, 57, 4570-4577.

43. Dreicer, R.; Stadler, W.M.; Ahmann, F.R.; Whiteside, T.; Bizouarne, N.; Acres, B.; Limacher, J.M.; Squiban, P.; Pantuck, A. MVA-MUC1-IL2 vaccine immunotherapy (TG4010) improves PSA doubling time in patients with prostate cancer with biochemical failure. Invest. New Drugs 2009, 27, 379-386.

44. Acres, B. Cancer immunotherapy: Phase II clinical studies with TG4010 (MVA-MUC1-IL2). J. BUON 2007, 12 (Suppl. 1), S71-S75.

45. Oudard, S.; Rixe, O.; Beuselinck, B.; Linassier, C.; Banu, E.; Machiels, J.P.; Baudard, M.; Ringeisen, F.; Velu, T.; Lefrere-Belda, M.A.; et al. A phase II study of the cancer vaccine TG4010 alone and in combination with cytokines in patients with metastatic renal clear-cell carcinoma: Clinical and immunological findings. Cancer Immunol. Immunother. 2011, 60, 261-271.

46. Butts, C.; Murray, N.; Maksymiuk, A.; Goss, G.; Marshall, E.; Soulieres, D.; Cormier, Y.; Ellis, P.; Price, A.; Sawhney, R.; et al. Randomized phase IIB trial of BLP25 liposome vaccine in stage IIIB and IV non-small-cell lung cancer. J. Clin. Oncol. 2005, 23, 6674-6681.

47. Testori, A.; Richards, J.; Whitman, E.; Mann, G.B.; Lutzky, J.; Camacho, L.; Parmiani, G.; Tosti, G.; Kirkwood, J.M.; Hoos, A.; et al. Phase III comparison of vitespen, an autologous tumorderived heat shock protein gp96 peptide complex vaccine, with physician's choice of treatment for stage IV melanoma: The C-100-21 Study Group. J. Clin. Onco.l 2008, 26, 955-962. 
48. Wood, C.; Srivastava, P.; Bukowski, R.; Lacombe, L.; Gorelov, A.I.; Gorelov, S.; Mulders, P.; Zielinski, H.; Hoos, A.; Teofilovici, F.; et al. An adjuvant autologous therapeutic vaccine (HSPPC-96; vitespen) versus observation alone for patients at high risk of recurrence after nephrectomy for renal cell carcinoma: A multicentre, open-label, randomised phase III trial. Lancet 2008, 372, 145-154.

49. Melief, C.J.; van der Burg, S.H. Immunotherapy of established (pre)malignant disease by synthetic long peptide vaccines. Nat. Rev. Cancer 2008, 8, 351-360.

50. Bijker, M.S.; van den Eeden, S.J.; Franken, K.L.; Melief, C.J.; van der Burg, S.H.; Offringa, R. Superior induction of anti-tumor CTL immunity by extended peptide vaccines involves prolonged, DC-focused antigen presentation. Eur. J. Immunol. 2008, 38, 1033-1042.

51. Jocham, D.; Richter, A.; Hoffmann, L.; Iwig, K.; Fahlenkamp, D.; Zakrzewski, G.; Schmitt, E.; Dannenberg, T.; Lehmacher, W.; von Wietersheim, J.; et al. Adjuvant autologous renal tumour cell vaccine and risk of tumour progression in patients with renal-cell carcinoma after radical nephrectomy: Phase III, randomised controlled trial. Lancet 2004, 363, 594-599.

52. Vermorken, J.B.; Claessen, A.M.; van Tinteren, H.; Gall, H.E.; Ezinga, R.; Meijer, S.; Scheper, R.J.; Meijer, C.J.; Bloemena, E.; Ransom, J.H.; et al. Active specific immunotherapy for stage II and stage III human colon cancer: A randomised trial. Lancet 1999, 353, 345-350.

53. Cassaday, R.D.; Sondel, P.M.; King, D.M.; Macklin, M.D.; Gan, J.; Warner, T.F.; Zuleger, C.L.; Bridges, A.J.; Schalch, H.G.; Kim, K.M.; et al. A phase I study of immunization using particlemediated epidermal delivery of genes for gp100 and GM-CSF into uninvolved skin of melanoma patients. Clin. Cancer Res. 2007, 13, 540-549.

54. McNeel, D.G.; Dunphy, E.J.; Davies, J.G.; Frye, T.P.; Johnson, L.E.; Staab, M.J.; Horvath, D.L.; Straus, J.; Alberti, D.; Marnocha, R.; et al. Safety and immunological efficacy of a DNA vaccine encoding prostatic acid phosphatase in patients with stage D0 prostate cancer. J. Clin. Oncol. 2009, 27, 4047-4054.

55. Michaluart, P.; Abdallah, K.A.; Lima, F.D.; Smith, R.; Moyses, R.A.; Coelho, V.; Victora, G.D.; Socorro-Silva, A.; Volsi, E.C.; Zarate-Blades, C.R.; et al. Phase I trial of DNA-hsp65 immunotherapy for advanced squamous cell carcinoma of the head and neck. Cancer Gene Ther. 2008, 15, 676-684.

56. Pavlenko, M.; Roos, A.K.; Lundqvist, A.; Palmborg, A.; Miller, A.M.; Ozenci, V.; Bergman, B.; Egevad, L.; Hellstrom, M.; Kiessling, R.; et al. A phase I trial of DNA vaccination with a plasmid expressing prostate-specific antigen in patients with hormone-refractory prostate cancer. Br. J. Cancer 2004, 91, 688-694.

57. Yuan, J.; Ku, G.Y.; Gallardo, H.F.; Orlandi, F.; Manukian, G.; Rasalan, T.S.; Xu, Y.; Li, H.; Vyas, S.; Mu, Z.; et al. Safety and immunogenicity of a human and mouse gp100 DNA vaccine in a phase I trial of patients with melanoma. Cancer Immun. 2009, 9, 5.

58. Caruso, D.A.; Orme, L.M.; Neale, A.M.; Radcliff, F.J.; Amor, G.M.; Maixner, W.; Downie, P.; Hassall, T.E.; Tang, M.L.; Ashley, D.M. Results of a phase 1 study utilizing monocyte-derived dendritic cells pulsed with tumor RNA in children and young adults with brain cancer. Neuro Oncol. 2004, 6, 236-246. 
59. Dannull, J.; Su, Z.; Rizzieri, D.; Yang, B.K.; Coleman, D.; Yancey, D.; Zhang, A.; Dahm, P.; Chao, N.; Gilboa, E.; Vieweg, J. Enhancement of vaccine-mediated antitumor immunity in cancer patients after depletion of regulatory T cells. J. Clin. Invest. 2005, 115, 3623-3633.

60. Kyte, J.A.; Mu, L.; Aamdal, S.; Kvalheim, G.; Dueland, S.; Hauser, M.; Gullestad, H.P.; Ryder, T.; Lislerud, K.; Hammerstad, H.; Gaudernack, G. Phase I/II trial of melanoma therapy with dendritic cells transfected with autologous tumor-mRNA. Cancer Gene Ther. 2006, 13, 905-918.

61. Su, Z.; Dannull, J.; Heiser, A.; Yancey, D.; Pruitt, S.; Madden, J.; Coleman, D.; Niedzwiecki, D.; Gilboa, E.; Vieweg, J. Immunological and clinical responses in metastatic renal cancer patients vaccinated with tumor RNA-transfected dendritic cells. Cancer Res. 2003, 63, 2127-2133.

62. Su, Z.; Dannull, J.; Yang, B.K.; Dahm, P.; Coleman, D.; Yancey, D.; Sichi, S.; Niedzwiecki, D.; Boczkowski, D.; Gilboa, E.; Vieweg, J. Telomerase mRNA-transfected dendritic cells stimulate antigen-specific CD8+ and CD4+ $\mathrm{T}$ cell responses in patients with metastatic prostate cancer. J. Immunol. 2005, 174, 3798-3807.

63. Weide, B.; Pascolo, S.; Scheel, B.; Derhovanessian, E.; Pflugfelder, A.; Eigentler, T.K.; Pawelec, G.; Hoerr, I.; Rammensee, H.G.; Garbe, C. Direct injection of protamine-protected mRNA: Results of a phase 1/2 vaccination trial in metastatic melanoma patients. J. Immunother. 2009, 32, 498-507.

64. Heiser, A.; Coleman, D.; Dannull, J.; Yancey, D.; Maurice, M.A.; Lallas, C.D.; Dahm, P.; Niedzwiecki, D.; Gilboa, E.; Vieweg, J. Autologous dendritic cells transfected with prostate-specific antigen RNA stimulate CTL responses against metastatic prostate tumors. J. Clin. Invest. 2002, 109, 409-417.

65. Apweiler, R.; Hermjakob, H.; Sharon, N. On the frequency of protein glycosylation, as deduced from analysis of the SWISS-PROT database. Biochim. Biophys. Acta 1999, 1473, 4-8.

66. Abdel-Motal, U.M.; Berg, L.; Rosen, A.; Bengtsson, M.; Thorpe, C.J.; Kihlberg, J.; Dahmen, J.; Magnusson, G.; Karlsson, K.A.; Jondal, M. Immunization with glycosylated Kb-binding peptides generates carbohydrate-specific, unrestricted cytotoxic T cells. Eur. J. Immunol. 1996, 26, 544-551.

67. Cobb, B.A.; Wang, Q.; Tzianabos, A.O.; Kasper, D.L. Polysaccharide processing and presentation by the MHCII pathway. Cell 2004, 117, 677-687.

68. Galli-Stampino, L.; Meinjohanns, E.; Frische, K.; Meldal, M.; Jensen, T.; Werdelin, O.; Mouritsen, S. T-cell recognition of tumor-associated carbohydrates: The nature of the glycan moiety plays a decisive role in determining glycopeptide immunogenicity. Cancer Res. 1997, 57, 3214-3222.

69. Haurum, J.S.; Arsequell, G.; Lellouch, A.C.; Wong, S.Y.; Dwek, R.A.; McMichael, A.J.; Elliott, T. Recognition of carbohydrate by major histocompatibility complex class I-restricted, glycopeptide-specific cytotoxic T lymphocytes. J. Exp. Med. 1994, 180, 739-744.

70. Haurum, J.S.; Hoier, I.B.; Arsequell, G.; Neisig, A.; Valencia, G.; Zeuthen, J.; Neefjes, J.; Elliott, T. Presentation of cytosolic glycosylated peptides by human class I major histocompatibility complex molecules in vivo. J. Exp. Med. 1999, 190, 145-150.

71. Rudd, P.M.; Elliott, T.; Cresswell, P.; Wilson, I.A.; Dwek, R.A. Glycosylation and the immune system. Science 2001, 291, 2370-2376.

72. Vlad, A.M.; Muller, S.; Cudic, M.; Paulsen, H.; Otvos, L., Jr.; Hanisch, F.G.; Finn, O.J. Complex carbohydrates are not removed during processing of glycoproteins by dendritic cells: Processing 
of tumor antigen MUC1 glycopeptides for presentation to major histocompatibility complex class II-restricted T cells. J. Exp. Med. 2002, 196, 1435-1446.

73. Werdelin, O.; Meldal, M.; Jensen, T. Processing of glycans on glycoprotein and glycopeptide antigens in antigen-presenting cells. Proc. Natl. Acad. Sci. USA 2002, 99, 9611-9613.

74. Brockhausen, I. Pathways of $O$-glycan biosynthesis in cancer cells. Biochim. Biophys. Acta 1999, 1473, 67-95.

75. Kornfeld, R.; Kornfeld, S. Assembly of asparagine-linked oligosaccharides. Annu. Rev. Biochem. 1985, 54, 631-664.

76. Brockhausen, I. Glycodynamics of mucin biosynthesis in gastrointestinal tumor cells. Adv. Exp. Med. Biol. 2003, 535, 163-188.

77. Hakomori, S. Aberrant glycosylation in tumors and tumor-associated carbohydrate antigens. Adv. Cancer Res. 1989, 52, 257-331.

78. Hakomori, S. Tumor-associated carbohydrate antigens defining tumor malignancy: Basis for development of anti-cancer vaccines. Adv. Exp. Med. Biol. 2001, 491, 369-402.

79. Kim, Y.J.; Varki, A. Perspectives on the significance of altered glycosylation of glycoproteins in cancer. Glycoconj. J. 1997, 14, 569-576.

80. Spiro, R.G. Protein glycosylation: Nature, distribution, enzymatic formation, and disease implications of glycopeptide bonds. Glycobiology 2002, 12, 43R-56R.

81. Sell, S. Cancer-associated carbohydrates identified by monoclonal antibodies. Hum. Pathol. 1990, 21, 1003-1019.

82. Fuster, M.M.; Esko, J.D. The sweet and sour of cancer: Glycans as novel therapeutic targets. Nat. Rev. Cancer 2005, 5, 526-542.

83. Livingston, P.O. Augmenting the immunogenicity of carbohydrate tumor antigens. Semin. Cancer Biol. 1995, 6, 357-366.

84. Livingston, P.O; Ragupathi, G. Cancer vaccines targeting carbohydrate antigens. Hum. Vaccin. 2006, 2, 137-143.

85. Sabbatini, P.J.; Ragupathi, G.; Hood, C.; Aghajanian, C.A.; Juretzka, M.; Iasonos, A.; Hensley, M.L.; Spassova, M.K.; Ouerfelli, O.; Spriggs, D.R.; et al. Pilot study of a heptavalent vaccinekeyhole limpet hemocyanin conjugate plus QS21 in patients with epithelial ovarian, fallopian tube, or peritoneal cancer. Clin. Cancer Res. 2007, 13, 4170-4177.

86. Retter, M.W.; Johnson, J.C.; Peckham, D.W.; Bannink, J.E.; Bangur, C.S.; Dresser, K.; Cai, F.; Foy, T.M.; Fanger, N.A.; Fanger, G.R.; et al. Characterization of a proapoptotic antiganglioside GM2 monoclonal antibody and evaluation of its therapeutic effect on melanoma and small cell lung carcinoma xenografts. Cancer Res. 2005, 65, 6425-6434.

87. Garcia, M.; Seigner, C.; Bastid, C.; Choux, R.; Payan, M.J.; Reggio, H. Carcinoembryonic antigen has a different molecular weight in normal colon and in cancer cells due to $N$-glycosylation differences. Cancer Res. 1991, 51, 5679-5686.

88. Hammarstrom, S. The carcinoembryonic antigen (CEA) family: Structures, suggested functions and expression in normal and malignant tissues. Semin. Cancer Biol. 1999, 9, 67-81.

89. Jankovic, M.M.; Kosanovic, M.M. Glycosylation of urinary prostate-specific antigen in benign hyperplasia and cancer: Assessment by lectin-binding patterns. Clin. Biochem. 2005, 38, 58-65. 
90. Matsuura, H.; Takio, K.; Titani, K.; Greene, T.; Levery, S.B.; Salyan, M.E.; Hakomori, S. The oncofetal structure of human fibronectin defined by monoclonal antibody FDC-6. Unique structural requirement for the antigenic specificity provided by a glycosylhexapeptide. J. Biol. Chem. 1988, 263, 3314-3322.

91. McNeel, D.G.; Nguyen, L.D.; Storer, B.E.; Vessella, R.; Lange, P.H.; Disis, M.L. Antibody immunity to prostate cancer associated antigens can be detected in the serum of patients with prostate cancer. J. Urol. 2000, 164, 1825-1829.

92. Meany, D.L.; Zhang, Z.; Sokoll, L.J.; Zhang, H.; Chan, D.W. Glycoproteomics for prostate cancer detection: Changes in serum PSA glycosylation patterns. J. Proteome Res. 2009, 8, 613-619.

93. Moss, E.L.; Hollingworth, J.; Reynolds, T.M. The role of CA125 in clinical practice. J. Clin. Pathol. 2005, 58, 308-312.

94. Cattaneo, A.; Biocca, S. The selection of intracellular antibodies. Trends Biotechnol. 1999, 17, 115-121.

95. Bouchet, J.; Basmaciogullari, S.E.; Chrobak, P.; Stolp, B.; Bouchard, N.; Fackler, O.T.; Chames, P.; Jolicoeur, P.; Benichou, S.; Baty, D. Inhibition of the Nef regulatory protein of HIV-1 by a single-domain antibody. Blood 2011, doi: 10.1182/blood-2010-07-296749.

96. Bai, J.; Sui, J.; Zhu, R.Y.; Tallarico, A.S.; Gennari, F.; Zhang, D.; Marasco, W.A. Inhibition of Tat-mediated transactivation and HIV-1 replication by human anti-hCyclinT1 intrabodies. J. Biol. Chem. 2003, 278, 1433-1442.

97. Goncalves, J.; Silva, F.; Freitas-Vieira, A.; Santa-Marta, M.; Malho, R.; Yang, X.; Gabuzda, D.; Barbas, C., 3rd. Functional neutralization of HIV-1 Vif protein by intracellular immunization inhibits reverse transcription and viral replication. J. Biol. Chem. 2002, 277, 32036-32045.

98. Levy-Mintz, P.; Duan, L.; Zhang, H.; Hu, B.; Dornadula, G.; Zhu, M.; Kulkosky, J.; BizubBender, D.; Skalka, A.M.; Pomerantz, R.J. Intracellular expression of single-chain variable fragments to inhibit early stages of the viral life cycle by targeting human immunodeficiency virus type 1 integrase. J. Virol. 1996, 70, 8821-8832.

99. Wu, Y.; Duan, L.; Zhu, M.; Hu, B.; Kubota, S.; Bagasra, O.; Pomerantz, R.J. Binding of intracellular anti-Rev single chain variable fragments to different epitopes of human immunodeficiency virus type 1 rev: Variations in viral inhibition. J. Virol. 1996, 70, 3290-3297.

100.Tse, E.; Rabbitts, T.H. Intracellular antibody-caspase-mediated cell killing: An approach for application in cancer therapy. Proc. Natl. Acad. Sci. USA 2000, 97, 12266-12271.

101. Alvarez, R.D.; Barnes, M.N.; Gomez-Navarro, J.; Wang, M.; Strong, T.V.; Arafat, W.; Arani, R.B.; Johnson, M.R.; Roberts, B.L.; Siegal, G.P.; et al. A cancer gene therapy approach utilizing an anti-erbB-2 single-chain antibody-encoding adenovirus (AD21): A phase I trial. Clin. Cancer Res. 2000, 6, 3081-3087.

102. Arafat, W.; Gomez-Navarro, J.; Xiang, J.; Siegal, G.P.; Alvarez, R.D.; Curiel, D.T. Antineoplastic effect of anti-erbB-2 intrabody is not correlated with scFv affinity for its target. Cancer Gene Ther. 2000, 7, 1250-1256.

103. Arafat, W.O.; Gomez-Navarro, J.; Buchsbaum, D.J.; Xiang, J.; Wang, M.; Casado, E.; Barker, S.D.; Mahasreshti, P.J.; Haisma, H.J.; Barnes, M.N.; et al. Effective single chain antibody (scFv) concentrations in vivo via adenoviral vector mediated expression of secretory scFv. Gene Ther. 2002, 9, 256-262. 
104. Deshane, J.; Siegal, G.P.; Alvarez, R.D.; Wang, M.H.; Feng, M.; Cabrera, G.; Liu, T.; Kay, M.; Curiel, D.T. Targeted tumor killing via an intracellular antibody against erbB-2. J. Clin. Invest. 1995, 96, 2980-2989.

105. Graus-Porta, D.; Beerli, R.R.; Hynes, N.E. Single-chain antibody-mediated intracellular retention of ErbB-2 impairs Neu differentiation factor and epidermal growth factor signaling. Mol. Cell. Biol. 1995, 15, 1182-1191.

106. Hyland, S.; Beerli, R.R.; Barbas, C.F.; Hynes, N.E.; Wels, W. Generation and functional characterization of intracellular antibodies interacting with the kinase domain of human EGF receptor. Oncogene 2003, 22, 1557-1567.

107. Richardson, J.H.; Hofmann, W.; Sodroski, J.G.; Marasco, W.A. Intrabody-mediated knockout of the high-affinity IL-2 receptor in primary human T cells using a bicistronic lentivirus vector. Gene Ther. 1998, 5, 635-644.

108. Richardson, J.H.; Sodroski, J.G.; Waldmann, T.A.; Marasco, W.A. Phenotypic knockout of the high-affinity human interleukin 2 receptor by intracellular single-chain antibodies against the alpha subunit of the receptor. Proc. Natl. Acad. Sci. USA 1995, 92, 3137-3141.

109. Strube, R.W.; Chen, S.Y. Characterization of anti-cyclin E single-chain Fv antibodies and intrabodies in breast cancer cells: Enhanced intracellular stability of novel sFv-F(c) intrabodies. J. Immunol. Methods 2002, 263, 149-167.

110. Tanaka, T.; Rabbitts, T.H. Intrabodies based on intracellular capture frameworks that bind the RAS protein with high affinity and impair oncogenic transformation. EMBO J. 2003, 22, 1025-1035.

111. Wadia, J.S.; Dowdy, S.F. Protein transduction technology. Curr. Opin. Biotechnol. 2002, 13, 52-56.

112. Allen, T.M. Ligand-targeted therapeutics in anticancer therapy. Nat. Rev. Cancer 2002, 2, 750-763.

113. Nielsen, U.B.; Kirpotin, D.B.; Pickering, E.M.; Hong, K.; Park, J.W.; Refaat Shalaby, M.; Shao, Y.; Benz, C.C.; Marks, J.D. Therapeutic efficacy of anti-ErbB2 immunoliposomes targeted by a phage antibody selected for cellular endocytosis. Biochim. Biophys. Acta 2002, 1591, 109-118.

114. Sapra, P.; Allen, T.M. Internalizing antibodies are necessary for improved therapeutic efficacy of antibody-targeted liposomal drugs. Cancer Res. 2002, 62, 7190-7194.

115. Kulasingam, V.; Diamandis, E.P. Strategies for discovering novel cancer biomarkers through utilization of emerging technologies. Nat. Clin. Pract. Oncol. 2008, 5, 588-599.

116. Ludwig, J.A.; Weinstein, J.N. Biomarkers in cancer staging, prognosis and treatment selection. Nat. Rev. Cancer 2005, 5, 845-856.

117. Shepard, H.M.; Jin, P.; Slamon, D.J.; Pirot, Z.; Maneval, D.C. Herceptin. Handb. Exp. Pharmacol. 2008, 183-219.

118. Gutierrez, C.; Schiff, R. HER2: Biology, detection, and clinical implications. Arch. Pathol. Lab. Med. 2011, 135, 55-62.

119. Kesisis, G.; Kontovinis, L.F.; Gennatas, K.; Kortsaris, A.H. Biological markers in breast cancer prognosis and treatment. J. BUON 2010, 15, 447-454.

120. de Snoo, F.; Bender, R.; Glas, A.; Rutgers, E. Gene expression profiling: Decoding breast cancer. Surg. Oncol. 2009, 18, 366-378.

121. Turaga, K.; Acs, G.; Laronga, C. Gene expression profiling in breast cancer. Cancer Control 2010, 17, 177-182. 
122. Guttman, A.; Csapo, Z.; Robbins, D. Rapid two-dimensional analysis of proteins by ultra-thin layer gel electrophoresis. Proteomics 2002, 2, 469-474.

123. O'Farrell, P.H. High resolution two-dimensional electrophoresis of proteins. J. Biol. Chem. 1975, 250, 4007-4021.

124.Lee, S.J.; Evers, S.; Roeder, D.; Parlow, A.F.; Risteli, J.; Risteli, L.; Lee, Y.C.; Feizi, T.; Langen, H.; Nussenzweig, M.C. Mannose receptor-mediated regulation of serum glycoprotein homeostasis. Science 2002, 295, 1898-1901.

125.Petricoin, E.F.; Ardekani, A.M.; Hitt, B.A.; Levine, P.J.; Fusaro, V.A.; Steinberg, S.M.; Mills, G.B.; Simone, C.; Fishman, D.A.; Kohn, E.C.; Liotta, L.A. Use of proteomic patterns in serum to identify ovarian cancer. Lancet 2002, 359, 572-577.

126. Janzi, M.; Odling, J.; Pan-Hammarstrom, Q.; Sundberg, M.; Lundeberg, J.; Uhlen, M.; Hammarstrom, L.; Nilsson, P. Serum microarrays for large scale screening of protein levels. Mol. Cell. Proteomics 2005, 4, 1942-1947.

127.Loch, C.M.; Ramirez, A.B.; Liu, Y.; Sather, C.L.; Delrow, J.J.; Scholler, N.; Garvik, B.M.; Urban, N.D.; McIntosh, M.W.; Lampe, P.D. Use of high density antibody arrays to validate and discover cancer serum biomarkers. Mol. Oncol. 2007, 1, 313-320.

128. Rosenberg, S.A. Progress in human tumour immunology and immunotherapy. Nature 2001, 411, 380-384.

129.Preuss, K.D.; Zwick, C.; Bormann, C.; Neumann, F.; Pfreundschuh, M. Analysis of the B-cell repertoire against antigens expressed by human neoplasms. Immunol. Rev. 2002, 188, 43-50.

130. Chen, Y.T. Cancer vaccine: Identification of human tumor antigens by SEREX. Cancer J. 2000, 6 (Suppl. 3), S208-S217.

131. Boel, P.; Wildmann, C.; Sensi, M.L.; Brasseur, R.; Renauld, J.C.; Coulie, P.; Boon, T.; van der Bruggen, P. BAGE: A new gene encoding an antigen recognized on human melanomas by cytolytic T lymphocytes. Immunity 1995, 2, 167-175.

132. Coulie, P.G.; Lehmann, F.; Lethe, B.; Herman, J.; Lurquin, C.; Andrawiss, M.; Boon, T. A mutated intron sequence codes for an antigenic peptide recognized by cytolytic T lymphocytes on a human melanoma. Proc. Natl. Acad. Sci. USA 1995, 92, 7976-7980.

133. Gaugler, B.; Van den Eynde, B.; van der Bruggen, P.; Romero, P.; Gaforio, J.J.; De Plaen, E.; Lethe, B.; Brasseur, F.; Boon, T. Human gene MAGE-3 codes for an antigen recognized on a melanoma by autologous cytolytic T lymphocytes. J. Exp. Med. 1994, 179, 921-930.

134. Rosenberg, S.A. A new era for cancer immunotherapy based on the genes that encode cancer antigens. Immunity 1999, 10, 281-287.

135.Cox, A.L.; Skipper, J.; Chen, Y.; Henderson, R.A.; Darrow, T.L.; Shabanowitz, J.; Engelhard, V.H.; Hunt, D.F.; Slingluff, C.L., Jr. Identification of a peptide recognized by five melanomaspecific human cytotoxic T cell lines. Science 1994, 264, 716-719.

136. Pascolo, S.; Schirle, M.; Guckel, B.; Dumrese, T.; Stumm, S.; Kayser, S.; Moris, A.; Wallwiener, D.; Rammensee, H.G.; Stevanovic, S. A MAGE-A1 HLA-A A*0201 epitope identified by mass spectrometry. Cancer Res. 2001, 61, 4072-4077.

137. Hunt, D.F.; Michel, H.; Dickinson, T.A.; Shabanowitz, J.; Cox, A.L.; Sakaguchi, K.; Appella, E.; Grey, H.M.; Sette, A. Peptides presented to the immune system by the murine class II major histocompatibility complex molecule I-Ad. Science 1992, 256, 1817-1820. 
138. Monach, P.A.; Meredith, S.C.; Siegel, C.T.; Schreiber, H. A unique tumor antigen produced by a single amino acid substitution. Immunity 1995, 2, 45-59.

139. Sahin, U.; Tureci, O.; Pfreundschuh, M. Serological identification of human tumor antigens. Curr. Opin. Immunol. 1997, 9, 709-716.

140. Tureci, O.; Sahin, U.; Pfreundschuh, M. Serological analysis of human tumor antigens: Molecular definition and implications. Mol. Med. Today 1997, 3, 342-349.

141. Gunawardana, C.G.; Diamandis, E.P. High throughput proteomic strategies for identifying tumour-associated antigens. Cancer Lett. 2007, 249, 110-119.

142. Jager, D. Potential target antigens for immunotherapy identified by serological expression cloning (SEREX). Methods Mol. Biol. 2007, 360, 319-326.

143. Tan, H.T.; Low, J.; Lim, S.G.; Chung, M.C. Serum autoantibodies as biomarkers for early cancer detection. FEBS J. 2009, 276, 6880-6904.

144. Bodovitz, S.; Joos, T. The proteomics bottleneck: Strategies for preliminary validation of potential biomarkers and drug targets. Trends Biotechnol. 2004, 22, 4-7.

145. Anderson, N.L.; Anderson, N.G. The human plasma proteome: History, character, and diagnostic prospects. Mol. Cell. Proteomics 2002, 1, 845-867.

146. Bodzon-Kulakowska, A.; Bierczynska-Krzysik, A.; Dylag, T.; Drabik, A.; Suder, P.; Noga, M.; Jarzebinska, J.; Silberring, J. Methods for samples preparation in proteomic research. J. Chromatogr. B Analyt. Technol. Biomed. Life Sci. 2007, 849, 1-31.

147. Jebrail, M.J.; Luk, V.N.; Shih, S.C.; Fobel, R.; Ng, A.H.; Yang, H.; Freire, S.L.; Wheeler, A.R. Digital microfluidics for automated proteomic processing. J. Vis. Exp. 2009, doi: 10.3791/1603.

148. Huang, H.L.; Stasyk, T.; Morandell, S.; Mogg, M.; Schreiber, M.; Feuerstein, I.; Huck, C.W.; Stecher, G.; Bonn, G.K.; Huber, L.A. Enrichment of low-abundant serum proteins by albumin/immunoglobulin $\mathrm{G}$ immunoaffinity depletion under partly denaturing conditions. Electrophoresis 2005, 26, 2843-2849.

149. Steel, L.F.; Trotter, M.G.; Nakajima, P.B.; Mattu, T.S.; Gonye, G.; Block, T. Efficient and specific removal of albumin from human serum samples. Mol. Cell. Proteomics 2003, 2, 262-270.

150. Pieper, R.; Gatlin, C.L.; Makusky, A.J.; Russo, P.S.; Schatz, C.R.; Miller, S.S.; Su, Q.; McGrath, A.M.; Estock, M.A.; Parmar, P.P.; et al. The human serum proteome: Display of nearly 3700 chromatographically separated protein spots on two-dimensional electrophoresis gels and identification of 325 distinct proteins. Proteomics 2003, 3, 1345-1364.

151. Gong, Y.; Li, X.; Yang, B.; Ying, W.; Li, D.; Zhang, Y.; Dai, S.; Cai, Y.; Wang, J.; He, F.; et al. Different immunoaffinity fractionation strategies to characterize the human plasma proteome. J. Proteome Res. 2006, 5, 1379-1387.

152. Chen, E.I.; Yates, J.R., 3rd. Cancer proteomics by quantitative shotgun proteomics. Mol. Oncol. 2007, 1, 144-159.

153. Lacroix, M.; Leclercq, G. Relevance of breast cancer cell lines as models for breast tumours: An update. Breast Cancer Res. Treat. 2004, 83, 249-289.

154. Vargo-Gogola, T.; Rosen, J.M. Modelling breast cancer: One size does not fit all. Nat. Rev. Cancer 2007, 7, 659-672. 
155. Krogh, A.; Larsson, B.; von Heijne, G.; Sonnhammer, E.L. Predicting transmembrane protein topology with a hidden Markov model: Application to complete genomes. J. Mol. Biol. 2001, 305, 567-580.

156. Pike, L.J. The challenge of lipid rafts. J. Lipid. Res. 2009, 50 (Suppl.), S323-S328.

157. Wallin, E.; von Heijne, G. Genome-wide analysis of integral membrane proteins from eubacterial, archaean, and eukaryotic organisms. Protein Sci. 1998, 7, 1029-1038.

158. Chambers, A.F.; Groom, A.C.; MacDonald, I.C. Dissemination and growth of cancer cells in metastatic sites. Nat. Rev. Cancer 2002, 2, 563-572.

159. Dowling, P.; Walsh, N.; Clynes, M. Membrane and membrane-associated proteins involved in the aggressive phenotype displayed by highly invasive cancer cells. Proteomics 2008, 8, 4054-4065.

160. Bergen, H.R., 3rd; Vasmatzis, G.; Cliby, W.A.; Johnson, K.L.; Oberg, A.L.; Muddiman, D.C. Discovery of ovarian cancer biomarkers in serum using NanoLC electrospray ionization TOF and FT-ICR mass spectrometry. Dis. Markers 2003, 19, 239-249.

161. Tammen, H.; Schulte, I.; Hess, R.; Menzel, C.; Kellmann, M.; Mohring, T.; Schulz-Knappe, P. Peptidomic analysis of human blood specimens: Comparison between plasma specimens and serum by differential peptide display. Proteomics 2005, 5, 3414-3422.

162. Chromy, B.A.; Gonzales, A.D.; Perkins, J.; Choi, M.W.; Corzett, M.H.; Chang, B.C.; Corzett, C.H.; McCutchen-Maloney, S.L. Proteomic analysis of human serum by two-dimensional differential gel electrophoresis after depletion of high-abundant proteins. J. Proteome Res. 2004, 3, 1120-1127.

163. Ramstrom, M.; Hagman, C.; Mitchell, J.K.; Derrick, P.J.; Hakansson, P.; Bergquist, J. Depletion of high-abundant proteins in body fluids prior to liquid chromatography fourier transform ion cyclotron resonance mass spectrometry. J. Proteome Res. 2005, 4, 410-416.

164.Zhang, R.; Barker, L.; Pinchev, D.; Marshall, J.; Rasamoelisolo, M.; Smith, C.; Kupchak, P.; Kireeva, I.; Ingratta, L.; Jackowski, G. Mining biomarkers in human sera using proteomic tools. Proteomics 2004, 4, 244-256.

165. Bjorhall, K.; Miliotis, T.; Davidsson, P. Comparison of different depletion strategies for improved resolution in proteomic analysis of human serum samples. Proteomics 2005, 5, 307-317.

166. Ahmed, N.; Barker, G.; Oliva, K.T.; Hoffmann, P.; Riley, C.; Reeve, S.; Smith, A.I.; Kemp, B.E.; Quinn, M.A.; Rice, G.E. Proteomic-based identification of haptoglobin-1 precursor as a novel circulating biomarker of ovarian cancer. Br. J. Cancer 2004, 91, 129-140.

167.Lopez, M.F.; Mikulskis, A.; Kuzdzal, S.; Bennett, D.A.; Kelly, J.; Golenko, E.; DiCesare, J.; Denoyer, E.; Patton, W.F.; Ediger, R.; et al. High-resolution serum proteomic profiling of Alzheimer disease samples reveals disease-specific, carrier-protein-bound mass signatures. Clin. Chem. 2005, 51, 1946-1954.

168.Zolotarjova, N.; Martosella, J.; Nicol, G.; Bailey, J.; Boyes, B.E.; Barrett, W.C. Differences among techniques for high-abundant protein depletion. Proteomics 2005, 5, 3304-3313.

169. Bhat, V.B.; Choi, M.H.; Wishnok, J.S.; Tannenbaum, S.R. Comparative plasma proteome analysis of lymphoma-bearing SJL mice. J. Proteome Res. 2005, 4, 1814-1825.

170. Govorukhina, N.I.; Reijmers, T.H.; Nyangoma, S.O.; van der Zee, A.G.; Jansen, R.C.; Bischoff, R. Analysis of human serum by liquid chromatography-mass spectrometry: Improved sample preparation and data analysis. J. Chromatogr. A 2006, 1120, 142-150. 
171.Echan, L.A.; Tang, H.Y.; Ali-Khan, N.; Lee, K.; Speicher, D.W. Depletion of multiple high-abundance proteins improves protein profiling capacities of human serum and plasma. Proteomics 2005, 5, 3292-3303.

172. Chou, P.H.; Chen, S.H.; Liao, H.K.; Lin, P.C.; Her, G.R.; Lai, A.C.; Chen, J.H.; Lin, C.C.; Chen, Y.J. Nanoprobe-based affinity mass spectrometry for selected protein profiling in human plasma. Anal. Chem. 2005, 77, 5990-5997.

173. Merrell, K.; Southwick, K.; Graves, S.W.; Esplin, M.S.; Lewis, N.E.; Thulin, C.D. Analysis of low-abundance, low-molecular-weight serum proteins using mass spectrometry. J. Biomol. Tech. 2004, 15, 238-248.

174. Aggelis, V.; Craven, R.A.; Peng, J.; Harnden, P.; Cairns, D.A.; Maher, E.R.; Tonge, R.; Selby, P.J.; Banks, R.E. Proteomic identification of differentially expressed plasma membrane proteins in renal cell carcinoma by stable isotope labelling of a von Hippel-Lindau transfectant cell line model. Proteomics 2009, 9, 2118-2130.

175.Conn, E.M.; Madsen, M.A.; Cravatt, B.F.; Ruf, W.; Deryugina, E.I.; Quigley, J.P. Cell surface proteomics identifies molecules functionally linked to tumor cell intravasation. J. Biol. Chem. 2008, 283, 26518-26527.

176. Qiu, H.; Wang, Y. Quantitative analysis of surface plasma membrane proteins of primary and metastatic melanoma cells. J. Proteome Res. 2008, 7, 1904-1915.

177. Konstantinopoulos, P.A.; Spentzos, D.; Cannistra, S.A. Gene-expression profiling in epithelial ovarian cancer. Nat. Clin. Pract. Oncol. 2008, 5, 577-587.

178. Bignotti, E.; Tassi, R.A.; Calza, S.; Ravaggi, A.; Romani, C.; Rossi, E.; Falchetti, M.; Odicino, F.E.; Pecorelli, S.; Santin, A.D. Differential gene expression profiles between tumor biopsies and short-term primary cultures of ovarian serous carcinomas: Identification of novel molecular biomarkers for early diagnosis and therapy. Gynecol. Oncol. 2006, 103, 405-416.

179. Meinhold-Heerlein, I.; Bauerschlag, D.; Zhou, Y.; Sapinoso, L.M.; Ching, K.; Frierson, H., Jr.; Brautigam, K.; Sehouli, J.; Stickeler, E.; Konsgen, D.; et al. An integrated clinical-genomics approach identifies a candidate multi-analyte blood test for serous ovarian carcinoma. Clin. Cancer Res. 2007, 13, 458-466.

180. Welsh, J.B.; Sapinoso, L.M.; Kern, S.G.; Brown, D.A.; Liu, T.; Bauskin, A.R.; Ward, R.L.; Hawkins, N.J.; Quinn, D.I.; Russell, P.J.; et al. Large-scale delineation of secreted protein biomarkers overexpressed in cancer tissue and serum. Proc. Natl. Acad. Sci. USA 2003, 100, 3410-3415.

181. Engvall, E.; Perlmann, P. Enzyme-linked immunosorbent assay (ELISA). Quantitative assay of immunoglobulin G. Immunochemistry 1971, 8, 871-874.

182. Campbell, G.T.; Bhatnagar, A.S. Simultaneous visualization by light microscopy of two pituitary hormones in a single tissue section using a combination of indirect immunohistochemical methods. J. Histochem. Cytochem. 1976, 24, 448-452.

183. Lathrop, J.T.; Hayes, T.K.; Carrick, K.; Hammond, D.J. Rarity gives a charm: Evaluation of trace proteins in plasma and serum. Expert Rev. Proteomics 2005, 2, 393-406.

184. Gharbi, S.; Gaffney, P.; Yang, A.; Zvelebil, M.J.; Cramer, R.; Waterfield, M.D.; Timms, J.F. Evaluation of two-dimensional differential gel electrophoresis for proteomic expression analysis of a model breast cancer cell system. Mol. Cell. Proteomics 2002, 1, 91-98. 
185. Lilley, K.S.; Razzaq, A.; Dupree, P. Two-dimensional gel electrophoresis: Recent advances in sample preparation, detection and quantitation. Curr. Opin. Chem. Biol. 2002, 6, 46-50.

186. Qin, S.; Ferdinand, A.S.; Richie, J.P.; O'Leary, M.P.; Mok, S.C.; Liu, B.C. Chromatofocusing fractionation and two-dimensional difference gel electrophoresis for low abundance serum proteins. Proteomics 2005, 5, 3183-3192.

187. Somiari, R.I.; Sullivan, A.; Russell, S.; Somiari, S.; Hu, H.; Jordan, R.; George, A.; Katenhusen, R.; Buchowiecka, A.; Arciero, C.; et al. High-throughput proteomic analysis of human infiltrating ductal carcinoma of the breast. Proteomics 2003, 3, 1863-1873.

188. Yu, K.H.; Rustgi, A.K.; Blair, I.A. Characterization of proteins in human pancreatic cancer serum using differential gel electrophoresis and tandem mass spectrometry. J. Proteome Res. 2005, 4, $1742-1751$.

189. Rui, Z.; Jian-Guo, J.; Yuan-Peng, T.; Hai, P.; Bing-Gen, R. Use of serological proteomic methods to find biomarkers associated with breast cancer. Proteomics 2003, 3, 433-439.

190. Unlu, M.; Morgan, M.E.; Minden, J.S. Difference gel electrophoresis: A single gel method for detecting changes in protein extracts. Electrophoresis 1997, 18, 2071-2077.

191. Kuwata, H.; Yip, T.T.; Yip, C.L.; Tomita, M.; Hutchens, T.W. Bactericidal domain of lactoferrin: Detection, quantitation, and characterization of lactoferricin in serum by SELDI affinity mass spectrometry. Biochem. Biophys. Res. Commun. 1998, 245, 764-773.

192. Bischoff, R.; Luider, T.M. Methodological advances in the discovery of protein and peptide disease markers. J. Chromatogr. B Analyt. Technol. Biomed. Life Sci. 2004, 803, 27-40.

193. Cazares, L.H.; Adam, B.L.; Ward, M.D.; Nasim, S.; Schellhammer, P.F.; Semmes, O.J.; Wright, G.L., Jr. Normal, benign, preneoplastic, and malignant prostate cells have distinct protein expression profiles resolved by surface enhanced laser desorption/ionization mass spectrometry. Clin. Cancer Res. 2002, 8, 2541-2552.

194.Petricoin, E.F., 3rd; Ornstein, D.K.; Paweletz, C.P.; Ardekani, A.; Hackett, P.S.; Hitt, B.A.; Velassco, A.; Trucco, C.; Wiegand, L.; Wood, K.; et al. Serum proteomic patterns for detection of prostate cancer. J. Natl. Cancer Inst. 2002, 94, 1576-1578.

195.Li, J.; Zhang, Z.; Rosenzweig, J.; Wang, Y.Y.; Chan, D.W. Proteomics and bioinformatics approaches for identification of serum biomarkers to detect breast cancer. Clin. Chem. 2002, 48, 1296-1304.

196. Ricolleau, G.; Charbonnel, C.; Lode, L.; Loussouarn, D.; Joalland, M.P.; Bogumil, R.; Jourdain, S.; Minvielle, S.; Campone, M.; Deporte-Fety, R.; et al. Surface-enhanced laser desorption/ionization time of flight mass spectrometry protein profiling identifies ubiquitin and ferritin light chain as prognostic biomarkers in node-negative breast cancer tumors. Proteomics 2006, 6, 1963-1975.

197. Rosty, C.; Christa, L.; Kuzdzal, S.; Baldwin, W.M.; Zahurak, M.L.; Carnot, F.; Chan, D.W.; Canto, M.; Lillemoe, K.D.; Cameron, J.L.; et al. Identification of hepatocarcinoma-intestinepancreas/pancreatitis-associated protein I as a biomarker for pancreatic ductal adenocarcinoma by protein biochip technology. Cancer Res. 2002, 62, 1868-1875.

198. Kozak, K.R.; Su, F.; Whitelegge, J.P.; Faull, K.; Reddy, S.; Farias-Eisner, R. Characterization of serum biomarkers for detection of early stage ovarian cancer. Proteomics 2005, 5, 4589-4596. 
199. Malik, G.; Ward, M.D.; Gupta, S.K.; Trosset, M.W.; Grizzle, W.E.; Adam, B.L.; Diaz, J.I.; Semmes, O.J. Serum levels of an isoform of apolipoprotein A-II as a potential marker for prostate cancer. Clin. Cancer Res. 2005, 11, 1073-1085.

200. Lebrecht, A.; Boehm, D.; Schmidt, M.; Koelbl, H.; Grus, F.H. Surface-enhanced laser desorption/ionisation time-of-flight mass spectrometry to detect breast cancer markers in tears and serum. Cancer Genomics Proteomics 2009, 6, 75-83.

201. Baggerly, K.A.; Morris, J.S.; Coombes, K.R. Reproducibility of SELDI-TOF protein patterns in serum: Comparing datasets from different experiments. Bioinformatics 2004, 20, 777-785.

202. Diamandis, E.P. Mass spectrometry as a diagnostic and a cancer biomarker discovery tool: Opportunities and potential limitations. Mol. Cell. Proteomics 2004, 3, 367-378.

203. Ornstein, D.K.; Gillespie, J.W.; Paweletz, C.P.; Duray, P.H.; Herring, J.; Vocke, C.D.; Topalian, S.L.; Bostwick, D.G.; Linehan, W.M.; Petricoin, E.F., 3rd; et al. Proteomic analysis of laser capture microdissected human prostate cancer and in vitro prostate cell lines. Electrophoresis 2000, 21, 2235-2242.

204. Bonner, R.F.; Emmert-Buck, M.; Cole, K.; Pohida, T.; Chuaqui, R.; Goldstein, S.; Liotta, L.A. Laser capture microdissection: Molecular analysis of tissue. Science 1997, 278, 1481,1483.

205. Simone, N.L.; Paweletz, C.P.; Charboneau, L.; Petricoin, E.F., 3rd; Liotta, L.A. Laser capture microdissection: Beyond functional genomics to proteomics. Mol. Diagn. 2000, 5, 301-307.

206. Allred, D.C.; Mohsin, S.K.; Fuqua, S.A. Histological and biological evolution of human premalignant breast disease. Endocr. Relat. Cancer 2001, 8, 47-61.

207. Fuller, A.P.; Palmer-Toy, D.; Erlander, M.G.; Sgroi, D.C. Laser capture microdissection and advanced molecular analysis of human breast cancer. J. Mammary Gland. Biol. Neoplasia 2003, $8,335-345$.

208. Sugiyama, Y.; Sugiyama, K.; Hirai, Y.; Akiyama, F.; Hasumi, K. Microdissection is essential for gene expression profiling of clinically resected cancer tissues. Am. J. Clin. Pathol. 2002, 117, 109-116.

209. Wulfkuhle, J.D.; McLean, K.C.; Paweletz, C.P.; Sgroi, D.C.; Trock, B.J.; Steeg, P.S.; Petricoin, E.F., 3rd New approaches to proteomic analysis of breast cancer. Proteomics 2001, 1, 1205-1215.

210. Gygi, S.P.; Rist, B.; Gerber, S.A.; Turecek, F.; Gelb, M.H.; Aebersold, R. Quantitative analysis of complex protein mixtures using isotope-coded affinity tags. Nat. Biotechnol. 1999, 17, 994-999.

211. Ross, P.L.; Huang, Y.N.; Marchese, J.N.; Williamson, B.; Parker, K.; Hattan, S.; Khainovski, N.; Pillai, S.; Dey, S.; Daniels, S.; et al. Multiplexed protein quantitation in Saccharomyces cerevisiae using amine-reactive isobaric tagging reagents. Mol. Cell. Proteomics 2004, 3, 1154-1169.

212. DeSouza, L.; Diehl, G.; Rodrigues, M.J.; Guo, J.; Romaschin, A.D.; Colgan, T.J.; Siu, K.W. Search for cancer markers from endometrial tissues using differentially labeled tags iTRAQ and cICAT with multidimensional liquid chromatography and tandem mass spectrometry. J. Proteome Res. 2005, 4, 377-386.

213. Yao, X.; Freas, A.; Ramirez, J.; Demirev, P.A.; Fenselau, C. Proteolytic 180 labeling for comparative proteomics: Model studies with two serotypes of adenovirus. Anal. Chem. 2001, 73, 2836-2842.

214. McDonald, W.H.; Yates, J.R., 3rd. Shotgun proteomics and biomarker discovery. Dis. Markers 2002, 18, 99-105. 
215. Koller, A.; Washburn, M.P.; Lange, B.M.; Andon, N.L.; Deciu, C.; Haynes, P.A.; Hays, L.; Schieltz, D.; Ulaszek, R.; Wei, J.; et al. Proteomic survey of metabolic pathways in rice. Proc. Natl. Acad. Sci. USA 2002, 99, 11969-11974.

216. Washburn, M.P.; Ulaszek, R.R.; Yates, J.R., 3rd. Reproducibility of quantitative proteomic analyses of complex biological mixtures by multidimensional protein identification technology. Anal. Chem. 2003, 75, 5054-5061.

217. Aebersold, R.; Mann, M. Mass spectrometry-based proteomics. Nature 2003, 422, 198-207.

218. Ewing, R.M.; Chu, P.; Elisma, F.; Li, H.; Taylor, P.; Climie, S.; McBroom-Cerajewski, L.; Robinson, M.D.; O'Connor, L.; Li, M.; et al. Large-scale mapping of human protein-protein interactions by mass spectrometry. Mol. Syst. Biol. 2007, 3, 89.

219. Markham, K.; Bai, Y.; Schmitt-Ulms, G. Co-immunoprecipitations revisited: An update on experimental concepts and their implementation for sensitive interactome investigations of endogenous proteins. Anal. Bioanal. Chem. 2007, 389, 461-473.

220. Nicol, G.R.; Han, M.; Kim, J.; Birse, C.E.; Brand, E.; Nguyen, A.; Mesri, M.; FitzHugh, W.; Kaminker, P.; Moore, P.A.; et al. Use of an immunoaffinity-mass spectrometry-based approach for the quantification of protein biomarkers from serum samples of lung cancer patients. Mol. Cell. Proteomics 2008, 7, 1974-1982.

221. Hoogenboom, H.R. Selecting and screening recombinant antibody libraries. Nat. Biotechnol. 2005, 23, 1105-1116.

222. Nielsen, U.B.; Marks, J.D. Internalizing antibodies and targeted cancer therapy: Direct selection from phage display libraries. Pharm. Sci. Technol. Today 2000, 3, 282-291.

223. Behar, G.; Chames, P.; Teulon, I.; Cornillon, A.; Alshoukr, F.; Roquet, F.; Pugniere, M.; Teillaud, J.L.; Gruaz-Guyon, A.; Pelegrin, A.; et al. Llama single-domain antibodies directed against nonconventional epitopes of tumor-associated carcinoembryonic antigen absent from nonspecific cross-reacting antigen. FEBS J. 2009, 276, 3881-3893.

224. Kastelic, D.; Frkovic-Grazio, S.; Baty, D.; Truan, G.; Komel, R.; Pompon, D. A single-step procedure of recombinant library construction for the selection of efficiently produced llama VH binders directed against cancer markers. J. Immunol. Methods 2009, 350, 54-62.

225. Marks, C.; Marks, J.D. Phage libraries-A new route to clinically useful antibodies. N. Engl. J. Med. 1996, 335, 730-733.

226. Sheets, M.D.; Amersdorfer, P.; Finnern, R.; Sargent, P.; Lindquist, E.; Schier, R.; Hemingsen, G.; Wong, C.; Gerhart, J.C.; Marks, J.D. Efficient construction of a large nonimmune phage antibody library: The production of high-affinity human single-chain antibodies to protein antigens. Proc. Natl. Acad. Sci. USA 1998, 95, 6157-6162.

227. Gao, C.; Mao, S.; Ronca, F.; Zhuang, S.; Quaranta, V.; Wirsching, P.; Janda, K.D. De novo identification of tumor-specific internalizing human antibody-receptor pairs by phage-display methods. J. Immunol. Methods 2003, 274, 185-197.

228. Geuijen, C.A.; Bijl, N.; Smit, R.C.; Cox, F.; Throsby, M.; Visser, T.J.; Jongeneelen, M.A.; Bakker, A.B.; Kruisbeek, A.M.; Goudsmit, J.; et al. A proteomic approach to tumour target identification using phage display, affinity purification and mass spectrometry. Eur. J. Cancer 2005, 41, 178-187. 
229. Heitner, T.; Moor, A.; Garrison, J.L.; Marks, C.; Hasan, T.; Marks, J.D. Selection of cell binding and internalizing epidermal growth factor receptor antibodies from a phage display library. J. Immunol. Methods 2001, 248, 17-30.

230. Liu, B.; Conrad, F.; Cooperberg, M.R.; Kirpotin, D.B.; Marks, J.D. Mapping tumor epitope space by direct selection of single-chain Fv antibody libraries on prostate cancer cells. Cancer Res. 2004, 64, 704-710.

231. Mazuet, C.; Lerouge, D.; Poul, M.A.; Blin, N. Breast carcinoma specific antibody selection combining phage display and immunomagnetic cell sorting. Biochem. Biophys. Res. Commun. 2006, 348, 550-559.

232. MacBeath, G.; Schreiber, S.L. Printing proteins as microarrays for high-throughput function determination. Science 2000, 289, 1760-1763.

233. Lal, S.P.; Christopherson, R.I.; dos Remedios, C.G. Antibody arrays: An embryonic but rapidly growing technology. Drug Discov. Today 2002, 7, S143-149.

234. Templin, M.F.; Stoll, D.; Schrenk, M.; Traub, P.C.; Vohringer, C.F.; Joos, T.O. Protein microarray technology. Drug Discov. Today 2002, 7, 815-822.

235. Wilson, D.S.; Nock, S. Recent developments in protein microarray technology. Angew. Chem. Int. Ed. Engl. 2003, 42, 494-500.

236. Houseman, B.T.; Huh, J.H.; Kron, S.J.; Mrksich, M. Peptide chips for the quantitative evaluation of protein kinase activity. Nat. Biotechnol. 2002, 20, 270-274.

237.Zhu, H.; Snyder, M. Protein chip technology. Curr. Opin. Chem. Biol. 2003, 7, 55-63.

238. MacBeath, G. Protein microarrays and proteomics. Nat. Genet. 2002, 32, 526-532.

239. Stromberg, S.; Bjorklund, M.G.; Asplund, C.; Skollermo, A.; Persson, A.; Wester, K.; Kampf, C.; Nilsson, P.; Andersson, A.C.; Uhlen, M.; et al. A high-throughput strategy for protein profiling in cell microarrays using automated image analysis. Proteomics 2007, 7, 2142-2150.

240. Kononen, J.; Bubendorf, L.; Kallioniemi, A.; Barlund, M.; Schraml, P.; Leighton, S.; Torhorst, J.; Mihatsch, M.J.; Sauter, G.; Kallioniemi, O.P. Tissue microarrays for high-throughput molecular profiling of tumor specimens. Nat. Med. 1998, 4, 844-847.

241. Lueking, A.; Horn, M.; Eickhoff, H.; Bussow, K.; Lehrach, H.; Walter, G. Protein microarrays for gene expression and antibody screening. Anal. Biochem. 1999, 270, 103-111.

242. Knezevic, V.; Leethanakul, C.; Bichsel, V.E.; Worth, J.M.; Prabhu, V.V.; Gutkind, J.S.; Liotta, L.A.; Munson, P.J.; Petricoin, E.F., 3rd; Krizman, D.B. Proteomic profiling of the cancer microenvironment by antibody arrays. Proteomics 2001, 1, 1271-1278.

243. Ge, H. UPA, a universal protein array system for quantitative detection of protein-protein, protein-DNA, protein-RNA and protein-ligand interactions. Nucl. Acid. Res. 2000, 28 , e3.

244. Arenkov, P.; Kukhtin, A.; Gemmell, A.; Voloshchuk, S.; Chupeeva, V.; Mirzabekov, A. Protein microchips: Use for immunoassay and enzymatic reactions. Anal. Biochem. 2000, 278, 123-131.

245.Haab, B.B.; Dunham, M.J.; Brown, P.O. Protein microarrays for highly parallel detection and quantitation of specific proteins and antibodies in complex solutions. Genome Biol. 2001, 2, RESEARCH0004.

246. Madoz-Gurpide, J.; Wang, H.; Misek, D.E.; Brichory, F.; Hanash, S.M. Protein based microarrays: A tool for probing the proteome of cancer cells and tissues. Proteomics 2001, 1, 1279-1287. 
247. Mendoza, L.G.; McQuary, P.; Mongan, A.; Gangadharan, R.; Brignac, S.; Eggers, M. High-throughput microarray-based enzyme-linked immunosorbent assay (ELISA). Biotechniques 1999, 27, 778-788.

248. Woodbury, R.L.; Varnum, S.M.; Zangar, R.C. Elevated HGF levels in sera from breast cancer patients detected using a protein microarray ELISA. J. Proteome Res. 2002, 1, 233-237.

249. Even-Desrumeaux, K.; Baty, D.; Chames, P. Strong and oriented immobilization of single domain antibodies from crude bacterial lysates for high-throughput compatible cost-effective antibody array generation. Mol. Biosyst. 2010, 6, 2241-2248.

250. Hsu, H.Y.; Wittemann, S.; Joos, T.O. Miniaturized parallelized sandwich immunoassays. Methods Mol. Biol. 2008, 428, 247-261.

251. Ramachandran, N.; Raphael, J.V.; Hainsworth, E.; Demirkan, G.; Fuentes, M.G.; Rolfs, A.; Hu, Y.; LaBaer, J. Next-generation high-density self-assembling functional protein arrays. Nat. Methods 2008, 5, 535-538.

252. Stemke-Hale, K.; Gonzalez-Angulo, A.M.; Lluch, A.; Neve, R.M.; Kuo, W.L.; Davies, M.; Carey, M.; Hu, Z.; Guan, Y.; Sahin, A.; et al. An integrative genomic and proteomic analysis of PIK3CA, PTEN, and AKT mutations in breast cancer. Cancer Res. 2008, 68, 6084-6091.

253. Rousserie, G.; Sukhanova, A.; Even-Desrumeaux, K.; Fleury, F.; Chames, P.; Baty, D.; Oleinikov, V.; Pluot, M.; Cohen, J.H.; Nabiev, I. Semiconductor quantum dots for multiplexed bio-detection on solid-state microarrays. Crit. Rev. Oncol. Hematol. 2010, 74, 1-15.

254.Hurst, R.; Hook, B.; Slater, M.R.; Hartnett, J.; Storts, D.R.; Nath, N. Protein-protein interaction studies on protein arrays: Effect of detection strategies on signal-to-background ratios. Anal. Biochem. 2009, 392, 45-53.

255. Iliopoulos, D.; Malizos, K.N.; Oikonomou, P.; Tsezou, A. Integrative microRNA and proteomic approaches identify novel osteoarthritis genes and their collaborative metabolic and inflammatory networks. PLoS One 2008, 3, e3740.

256. Morgan, E.; Varro, R.; Sepulveda, H.; Ember, J.A.; Apgar, J.; Wilson, J.; Lowe, L.; Chen, R.; Shivraj, L.; Agadir, A.; et al. Cytometric bead array: A multiplexed assay platform with applications in various areas of biology. Clin. Immunol. 2004, 110, 252-266.

257. Paweletz, C.P.; Charboneau, L.; Bichsel, V.E.; Simone, N.L.; Chen, T.; Gillespie, J.W.; EmmertBuck, M.R.; Roth, M.J.; Petricoin, I.E.; Liotta, L.A. Reverse phase protein microarrays which capture disease progression show activation of pro-survival pathways at the cancer invasion front. Oncogene 2001, 20, 1981-1989.

258. Sheehan, K.M.; Calvert, V.S.; Kay, E.W.; Lu, Y.; Fishman, D.; Espina, V.; Aquino, J.; Speer, R.; Araujo, R.; Mills, G.B.; et al. Use of reverse phase protein microarrays and reference standard development for molecular network analysis of metastatic ovarian carcinoma. Mol. Cell. Proteomics 2005, 4, 346-355.

259. Poetz, O.; Schwenk, J.M.; Kramer, S.; Stoll, D.; Templin, M.F.; Joos, T.O. Protein microarrays: Catching the proteome. Mech. Ageing Dev. 2005, 126, 161-170.

260. Templin, M.F.; Stoll, D.; Schwenk, J.M.; Potz, O.; Kramer, S.; Joos, T.O. Protein microarrays: Promising tools for proteomic research. Proteomics 2003, 3, 2155-2166.

261. Proll, G.; Steinle, L.; Proll, F.; Kumpf, M.; Moehrle, B.; Mehlmann, M.; Gauglitz, G. Potential of label-free detection in high-content-screening applications. J. Chromatogr. A 2007, 1161, 2-8. 
262. McDonnell, J.M. Surface plasmon resonance: Towards an understanding of the mechanisms of biological molecular recognition. Curr. Opin. Chem. Biol. 2001, 5, 572-577.

263. Wegner, G.J.; Wark, A.W.; Lee, H.J.; Codner, E.; Saeki, T.; Fang, S.; Corn, R.M. Real-time surface plasmon resonance imaging measurements for the multiplexed determination of protein adsorption/desorption kinetics and surface enzymatic reactions on peptide microarrays. Anal. Chem. 2004, 76, 5677-5684.

264. Yu, X.; Xu, D.; Cheng, Q. Label-free detection methods for protein microarrays. Proteomics 2006, 6, 5493-5503.

265. Borch, J.; Roepstorff, P. Screening for enzyme inhibitors by surface plasmon resonance combined with mass spectrometry. Anal. Chem. 2004, 76, 5243-5248.

266. McLafferty, F.W.; Fridriksson, E.K.; Horn, D.M.; Lewis, M.A.; Zubarev, R.A. Techview: Biochemistry. Biomolecule mass spectrometry. Science 1999, 284, 1289-1290.

267.Zheng, G.; Patolsky, F.; Cui, Y.; Wang, W.U.; Lieber, C.M. Multiplexed electrical detection of cancer markers with nanowire sensor arrays. Nat. Biotechnol. 2005, 23, 1294-1301.

268. Zhukov, A.; Schurenberg, M.; Jansson, O.; Areskoug, D.; Buijs, J. Integration of surface plasmon resonance with mass spectrometry: Automated ligand fishing and sample preparation for MALDI MS using a Biacore 3000 biosensor. J. Biomol. Tech. 2004, 15, 112-119.

269. Wan, W.H.; Fortuna, M.B.; Furmanski, P. A rapid and efficient method for testing immunohistochemical reactivity of monoclonal antibodies against multiple tissue samples simultaneously. J. Immunol. Methods 1987, 103, 121-129.

270. Schoenberg Fejzo, M.; Slamon, D.J. Frozen tumor tissue microarray technology for analysis of tumor RNA, DNA, and proteins. Am. J. Pathol. 2001, 159, 1645-1650.

271.Li, R.; Ni, J.; Bourne, P.A.; Yeh, S.; Yao, J.; di Sant'Agnese, P.A.; Huang, J. Cell culture block array for immunocytochemical study of protein expression in cultured cells. Appl. Immunohistochem. Mol. Morphol. 2005, 13, 85-90.

272. Montgomery, K.; Zhao, S.; van de Rijn, M.; Natkunam, Y. A novel method for making "tissue" microarrays from small numbers of suspension cells. Appl. Immunohistochem. Mol. Morphol. 2005, 13, 80-84.

273. Datta, M.W.; Kahler, A.; Macias, V.; Brodzeller, T.; Kajdacsy-Balla, A. A simple inexpensive method for the production of tissue microarrays from needle biopsy specimens: Examples with prostate cancer. Appl. Immunohistochem. Mol. Morphol. 2005, 13, 96-103.

274.Camp, R.L.; Charette, L.A.; Rimm, D.L. Validation of tissue microarray technology in breast carcinoma. Lab. Invest. 2000, 80, 1943-1949.

275. Torhorst, J.; Bucher, C.; Kononen, J.; Haas, P.; Zuber, M.; Kochli, O.R.; Mross, F.; Dieterich, H.; Moch, H.; Mihatsch, M.; et al. Tissue microarrays for rapid linking of molecular changes to clinical endpoints. Am. J. Pathol. 2001, 159, 2249-2256.

276. Persson, A.; Hober, S.; Uhlen, M. A human protein atlas based on antibody proteomics. Curr. Opin. Mol. Ther. 2006, 8, 185-190.

277. Lehmann, F.; Tiralongo, E.; Tiralongo, J. Sialic acid-specific lectins: Occurrence, specificity and function. Cell. Mol. Life Sci. 2006, 63, 1331-1354. 
278. Block, T.M.; Comunale, M.A.; Lowman, M.; Steel, L.F.; Romano, P.R.; Fimmel, C.; Tennant, B.C.; London, W.T.; Evans, A.A.; Blumberg, B.S.; et al. Use of targeted glycoproteomics to identify serum glycoproteins that correlate with liver cancer in woodchucks and humans. Proc. Natl. Acad. Sci. USA 2005, 102, 779-784.

279. Dube, D.H.; Bertozzi, C.R. Glycans in cancer and inflammation-Potential for therapeutics and diagnostics. Nat. Rev. Drug Discov. 2005, 4, 477-488.

280. Peracaula, R.; Barrabes, S.; Sarrats, A.; Rudd, P.M.; de Llorens, R. Altered glycosylation in tumours focused to cancer diagnosis. Dis. Markers 2008, 25, 207-218.

281. Perkins, G.L.; Slater, E.D.; Sanders, G.K.; Prichard, J.G. Serum tumor markers. Am. Fam. Phys. 2003, 68, 1075-1082.

282. Shariat, S.F.; Karam, J.A.; Margulis, V.; Karakiewicz, P.I. New blood-based biomarkers for the diagnosis, staging and prognosis of prostate cancer. BJU Int. 2008, 101, 675-683.

283. Selby, D.S.; Larsen, M.R.; Calvano, C.D.; Jensen, O.N. Identification and characterization of $N$-glycosylated proteins using proteomics. Methods Mol. Biol. 2008, 484, 263-276.

284. Taylor, A.D.; Hancock, W.S.; Hincapie, M.; Taniguchi, N.; Hanash, S.M. Towards an integrated proteomic and glycomic approach to finding cancer biomarkers. Genome Med. 2009, 1, 57.

285. Wang, Y.; Ao, X.; Vuong, H.; Konanur, M.; Miller, F.R.; Goodison, S.; Lubman, D.M. Membrane glycoproteins associated with breast tumor cell progression identified by a lectin affinity approach. J. Proteome Res. 2008, 7, 4313-4325.

286. Cho, W.; Jung, K.; Regnier, F.E. Use of glycan targeting antibodies to identify cancer-associated glycoproteins in plasma of breast cancer patients. Anal. Chem. 2008, 80, 5286-5292.

287. Dalpathado, D.S.; Desaire, H. Glycopeptide analysis by mass spectrometry. Analyst 2008, 133, 731-738.

288. Powlesland, A.S.; Hitchen, P.G.; Parry, S.; Graham, S.A.; Barrio, M.M.; Elola, M.T.; Mordoh, J.; Dell, A.; Drickamer, K.; Taylor, M.E. Targeted glycoproteomic identification of cancer cell glycosylation. Glycobiology 2009, 19, 899-909.

289. Comunale, M.A.; Wang, M.; Hafner, J.; Krakover, J.; Rodemich, L.; Kopenhaver, B.; Long, R.E.; Junaidi, O.; Bisceglie, A.M.; Block, T.M.; et al. Identification and development of fucosylated glycoproteins as biomarkers of primary hepatocellular carcinoma. J. Proteome Res. 2009, 8, 595-602.

290. Jung, K.; Cho, W.; Regnier, F.E. Glycoproteomics of plasma based on narrow selectivity lectin affinity chromatography. J. Proteome Res. 2009, 8, 643-650.

291.Xiong, L.; Andrews, D.; Regnier, F. Comparative proteomics of glycoproteins based on lectin selection and isotope coding. J. Proteome Res. 2003, 2, 618-625.

292.Larsen, M.R.; Trelle, M.B.; Thingholm, T.E.; Jensen, O.N. Analysis of posttranslational modifications of proteins by tandem mass spectrometry. Biotechniques 2006, 40, 790-798.

293. Moore, A.; Medarova, Z.; Potthast, A.; Dai, G. In vivo targeting of underglycosylated MUC-1 tumor antigen using a multimodal imaging probe. Cancer Res. 2004, 64, 1821-1827.

(C) 2011 by the authors; licensee MDPI, Basel, Switzerland. This article is an open access article distributed under the terms and conditions of the Creative Commons Attribution license (http://creativecommons.org/licenses/by/3.0/). 